\title{
France: 2010 Article IV Consultation-Staff Report; Staff Supplement; Public Information Notice on the Executive Board Discussion; and Statement by the Executive Director for France
}

Under Article IV of the IMF's Articles of Agreement, the IMF holds bilateral discussions with members, usually every year. In the context of the 2010 Article IV consultation with France, the following documents have been released and are included in this package:

- The staff report for the 2010 Article IV consultation, prepared by a staff team of the IMF, following discussions that ended on June 15, 2010, with the officials of France on economic developments and policies. Based on information available at the time of these discussions, the staff report was completed on July 13, 2010. The views expressed in the staff report are those of the staff team and do not necessarily reflect the views of the Executive Board of the IMF.

- $\quad$ A staff supplement of July 27, 2010 updating information on recent developments.

- $\quad$ A Public Information Notice (PIN) summarizing the views of the Executive Board as expressed during its July 28, 2010 discussion of the staff report that concluded the Article IV consultation.

- $\quad$ A statement by the Executive Director for France.

The document listed below has been or will be separately released.

\section{Selected Issues Paper}

The policy of publication of staff reports and other documents allows for the deletion of market-sensitive information.

\author{
Copies of this report are available to the public from \\ International Monetary Fund • Publication Services \\ $70019^{\text {th }}$ Street, N.W. $\bullet$ Washington, D.C. 20431 \\ Telephone: (202) 623-7430 • Telefax: (202) 623-7201 \\ E-mail: publications@imf.org Internet: http://www.imf.org
}

Price: $\$ 18.00$ a copy

\section{International Monetary Fund Washington, D.C.}




\title{
INTERNATIONAL MONETARY FUND
}

\section{FRANCE}

\section{Staff Report for the 2010 Article IV Consultation}

\author{
Prepared by the Staff Representatives for the 2010 Consultation with France
}

Approved by Poul M. Thomsen and Martin Mühleisen

July 13,2010

Context: A gradual recovery is underway in France but downside risks to the outlook have increased amid concerns about sovereign risks in Europe and uncertainties about the institutional underpinnings of the euro. The financial crisis cum recession have exerted a large toll on public finances, and in the financial sector concerns remain about asset quality, possible spillovers from mature markets, and regulatory uncertainty.

Challenges: Appropriate policy response succeeded in stabilizing the financial system and cushioning the downturn. The consultation focused on the need for credible consolidation to safeguard fiscal sustainability without endangering the fragile recovery; putting in place measures to deal with financial stability risks and prospective regulatory requirements; and structural reforms to improve competitiveness, create jobs, and increase growth.

Authorities' response: The authorities agreed that strong fiscal adjustment is needed to ensure sustainable public finances, and were committed to reducing the overall deficit to 3 percent of GDP deficit by 2013. While acknowledging staff's assessment of risks in the banking sector, they emphasized that the system is sound but expressed concern about the possible adverse impact on the economy of some new regulatory proposals. The authorities agreed with the importance of fully implementing their ambitious structural reform agenda.

Previous IMF advice: Policy formulation and implementation have generally been consistent with Executive Board recommendations. The fiscal stimulus in 2009-10 and the measures to support the banking sector were in line with what was envisaged in the last Article IV consultation. The authorities agreed with the need for structural reforms and have continued to implement their agenda in this area.

Mission team: Ms. Gulde-Wolf (head), Mr. De Vrijer, Mr. Cheng, Ms. Tytell, Ms. Xiao (all EUR), and Ms. Yakadina (FAD). Staff met with Minister of Economy, Industry, and Employment Lagarde, Minister of the Budget, the Civil Service, and the Reform of the State Baroin, Minister for Labor, Social Affairs, and the Pension Reform Woerth, Deputy Governor of the Banque de France Redouin, other senior officials, and representatives of Parliament and the private sector. Messrs. Fayolle or Ducrocq (OED) attended the meetings. 
I. Context: From Recession to Recovery .......................................................................

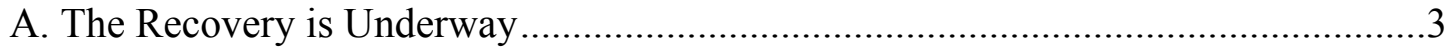

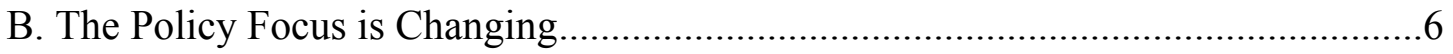

II. Outlook and Risks: A Gradual Rebound and Challenges Ahead......................................9

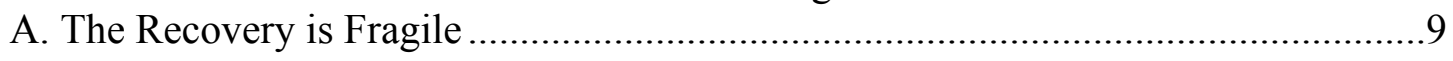

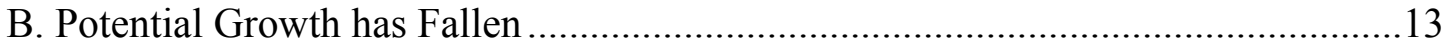

III. Policy Challenges: Safeguarding Fiscal Sustainability, Ensuring Financial Stability, and

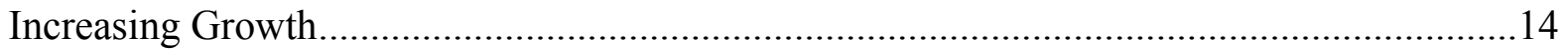

A. Fiscal Sustainability: Achieving a Large and Durable Consolidation ....................14

B. Financial Stability: Towards a Safer and More Resilient Financial Sector ............20

C. Increasing Growth: Modernizing the Economic Structure .................................24

IV. Staff Appraisal

Figures

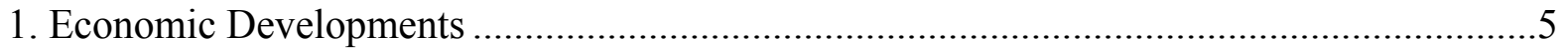

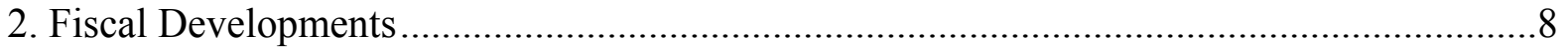

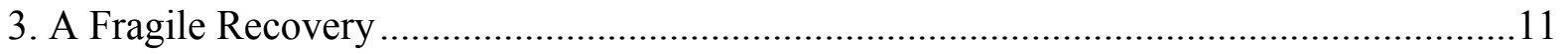

4. Competitiveness and External Performance ...............................................................27

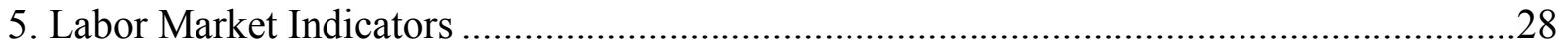

Tables

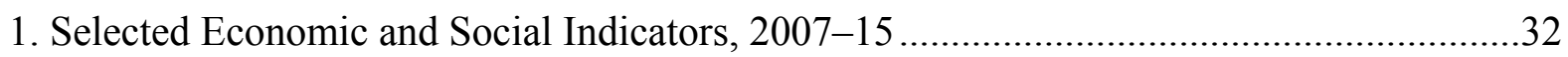

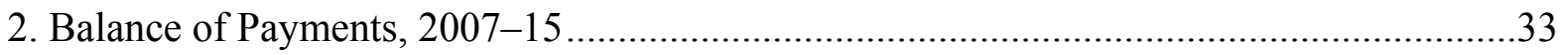

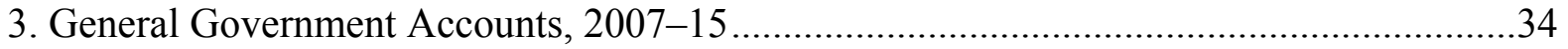

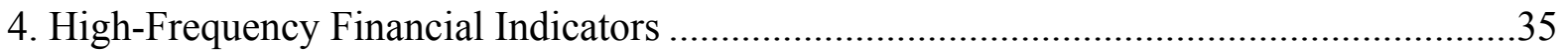

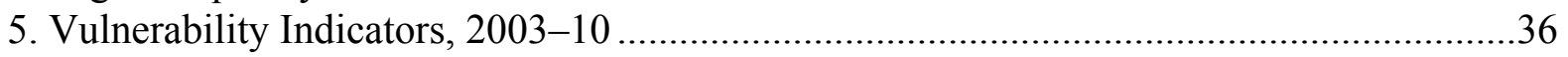

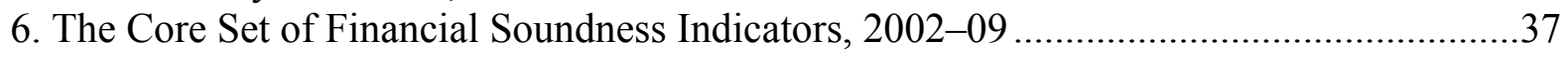

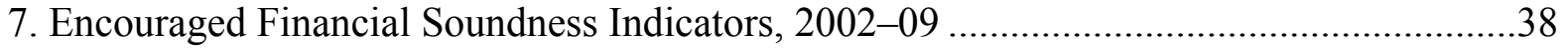

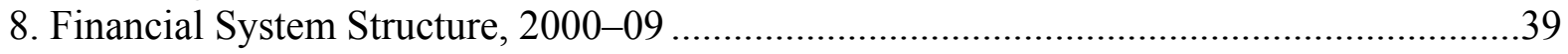

\section{Boxes}

1. The Impact of the Car Scrapping Program ..................................................................

2. Key Measures Taken by the Government to Support the Economy................................... 7

3. The French Recovery in Historical Context .............................................................. 10

4. The 2010 Tax Reform in France...............................................................................15

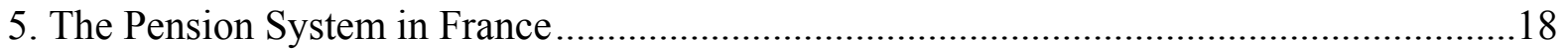

6. Strengthening Macro Framework for the Multiyear Budgets........................................20

7. Exposures of French Banks to Greece, Ireland, Italy, Portugal, and Spain (GIIPS) ..........22

8. Why has Unemployment Increased so Much?..........................................................27 


\section{CONTEXT: From ReCESSION to RECOVERY}

\section{A. The Recovery is Underway}

1. Following a less severe recession than in most other advanced economies, a fragile recovery in underway. France outperformed its peers in 2009, with real GDP contracting by $2 \frac{1}{2}$ percent, compared to a downturn of 5 percent in both Germany and Italy and about 4 percent in the Euro Area as a whole. The relatively less severe downturn in France reflects the comparatively low trade openness, a fairly resilient financial sector, the large social safety net, and timely and decisive government intervention. The French economy exited the recession in 2009:Q2, but the recovery is being tested in the first part of 2010 by weakening household confidence and demand amid market concerns about

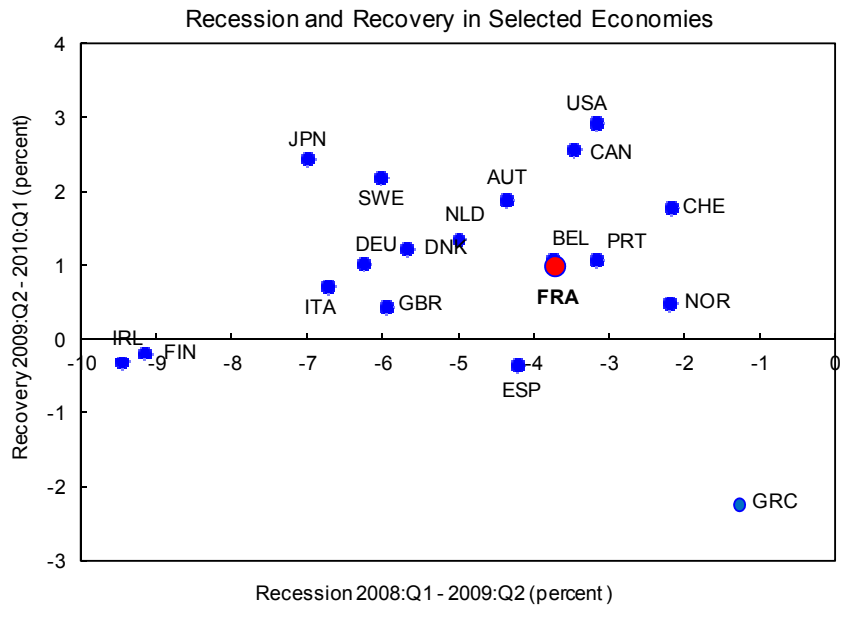

Source: WEO, and IMF staff estimates. sovereign risks in the Euro Area.

2. The recovery has been driven by private consumption and net exports, as well as a turn in the inventory cycle. Household spending received a significant boost from the government stimulus measures, notably the car scrapping scheme (Box 1), although automobile purchases plummeted in early 2010 as a result of payback effects. Fixed investment declined throughout 2009 and in the first quarter of 2010 despite substantial public intervention (Figure 1). Net exports have supported the recovery as foreign demand picked up, although imports strengthened toward the end of 2009 and in early 2010. At the same time, the large output gap has kept inflation low, despite the rebound in commodity prices.

3. Notwithstanding the rebound, the unemployment rate continued to increase, notably among the young. After reaching a low of 7.2 percent in June 2008, the unemployment rate has risen steeply and stood at $9 \frac{1}{2}$ percent as of May 2010. The increase is larger than expected given the depth of the downturn, likely reflecting, in part, the adjustment in specific sectors, including financial services and construction, where the reduction in employment has likely exceeded the output decline. 


\section{Box 1. The Impact of the Car Scrapping Program}

The French car scrapping scheme (prime à la casse) was launched in January 2009 as a part of the fiscal stimulus package. The program introduced a bonus of $€ 1,000$ off the price of a new car with emissions under $160 \mathrm{~g} \mathrm{CO} 2 / \mathrm{km}$ if the buyer scraps a car that is more than 10 years old in the course of 2009. While the scheme remains in place through the end of 2010, the size of the bonus dropped to $€ 700$ in January and is set to further diminish to $€ 500$ in July. The total amount of the program is $€ 620$ million, or about 0.03 percent of GDP. In addition, a state guarantee for car loans in the amount of $€ 6.5$ million and several eco-friendly tax measures have also been introduced. Finally, France has likely indirectly benefitted from the German car scrapping program.

Staff estimates suggest that the scheme's effects can account for the bulk of private consumption growth in 2009. The behavior of private expenditure on cars since 2000 can be explained by a simple model including gasoline price growth, two lags of the dependent variable, and a moving average term. However, this model cannot explain the rise in car sales during 2009. Dummy variables for the four quarters of 2009 suggest that the car scrapping scheme raised car consumption growth by about 5 percentage points, on average, with the strongest effect in Q4. These effects translate into a contribution to total private consumption growth in 2009 of 0.3 percentage points, on average, in quarter-on-quarter terms and 0.6 percentage points in year-on-year terms. In actuality, private consumption in 2009 grew by 0.4 percentage points, on average, in quarter-on-quarter terms and 0.9 percentage points in year-on-year terms.

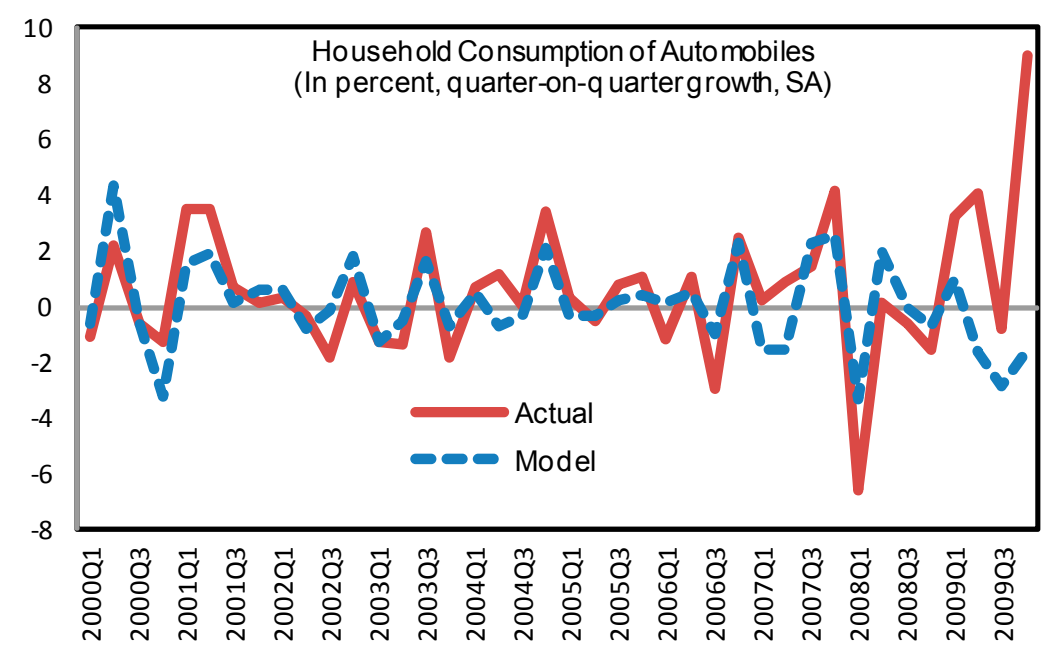

Source: Haver Analytics, and IMF staff estimates.

Following the success of the scheme during 2009, auto sales plummeted and lowered private consumption growth in early 2010. The phasing out of the car scrapping scheme gave rise to the "payback effect" of the inter-temporal shift in vehicle purchases. Although it may have been mitigated to the extent that the scheme had crowded out other private spending, the effect was still significant. This dynamic is in line with past experiences, as France saw sharp declines in car sales following previous scrapping schemes introduced in the 1990s. 
Figure 1. France: Economic Developments

(Percent change)
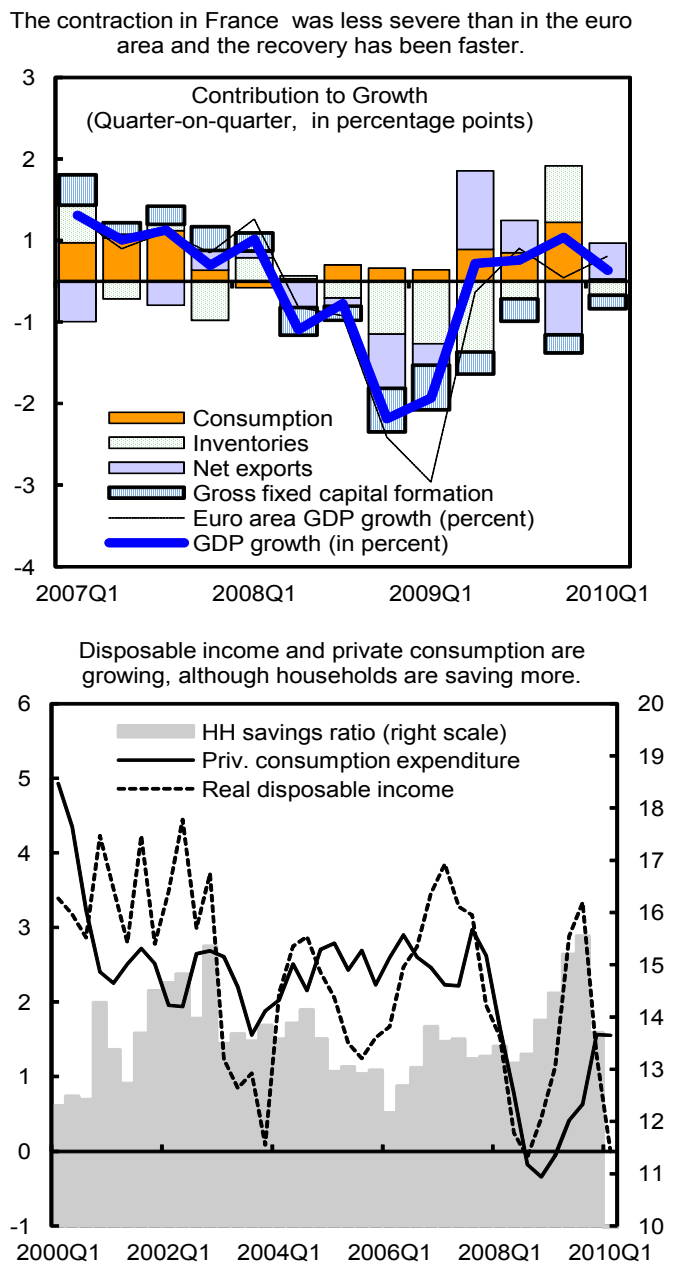

However, unemployment rate has risen

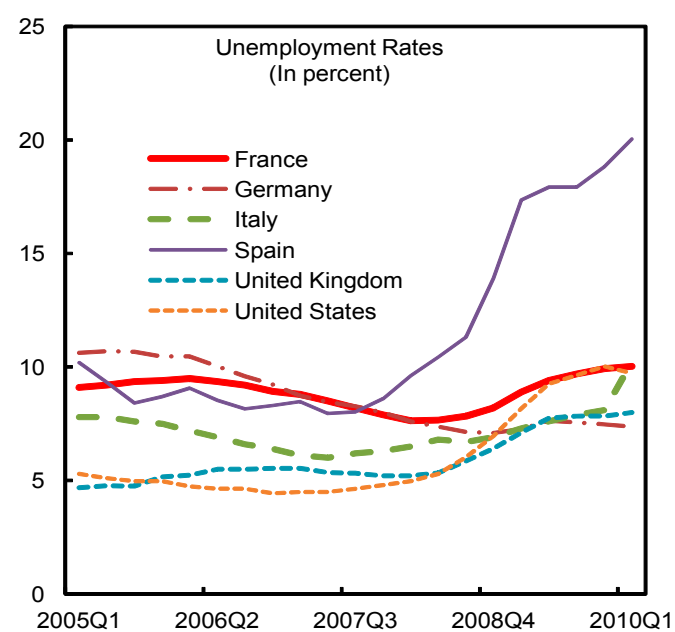

Domestic demand is on the rebound and the external sector is supporting the recovery.

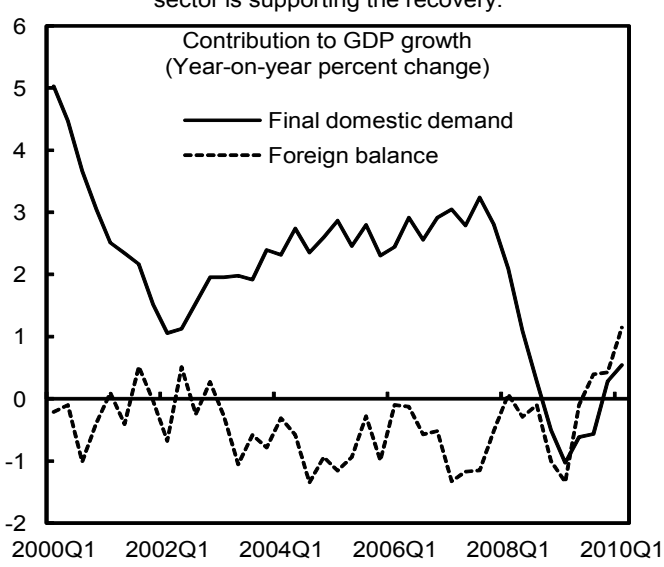

Inventory decumulation has slowed.

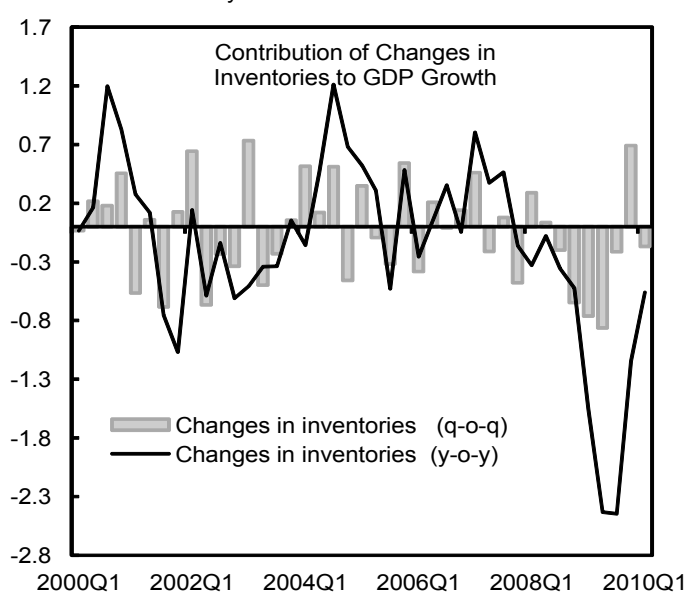

... while private credit growth remains sluggish.

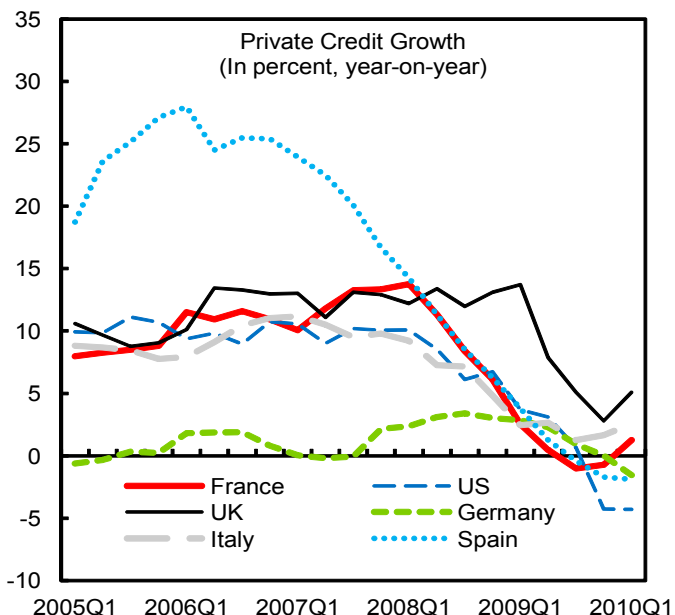

Sources: Global Insight/Datalnsight, and IMF, World Economic Outlook. 
4. Although financial conditions have improved, credit growth remains depressed. The global financial crisis has had a relatively less negative impact on French banks than on most European peers, in part reflecting their comparatively conservative lending practices and the consistent supervisory coverage of all lending institutions. Nevertheless, asset quality has worsened and additional writedowns on risky assets are likely. Private credit growth has remained sluggish but available evidence suggests that loan developments, especially in the corporate sector, are driven more by depressed credit demand than by short supply (see Analytical Note 1).

5. Sovereign spreads remain moderate, but concerns over sovereign risks linger. The debt crisis in Greece and widespread concerns about its repercussions for other vulnerable members of the Euro Area continue to influence the economic agenda in the region. That said, the spread over German Bunds remains moderate. French banks have relatively large exposures to Greece, Ireland, Italy, Portugal, and Spain that account for seven percent of bank assets and 30 percent of GDP. These exposures are dominated by holdings of private Italian and Spanish debt, while sovereign debt positions in Greece are small.

\section{B. The Policy Focus is Changing}

\section{The policy focus is shifting from crisis management to strengthening the}

foundations of the economy. The authorities have taken important policy actions to stabilize the financial system and implemented a suitable fiscal stimulus package to cushion the downturn (Box 2). As the recovery gains momentum, the policy focus is on fiscal consolidation, better financial regulation, and structural reforms to raise potential growth and strengthen competitiveness. At the same time, the authorities need to stand ready to take action to support the banking sector if the sovereign near-crisis worsens.

\section{In public finances, the focus is moving from supporting demand to fiscal} consolidation, as both the deficit and the debt have risen sharply. With the operation of automatic stabilizers and discretionary fiscal measures, the general government deficit rose from 3.3 percent of GDP in 2008 to 7.5 percent in 2009 (Figure 2). For 2010, a deficit of 8 percent of GDP is expected. France has been under the excessive deficit procedure (EDP) of the European Commission since February 2009. ${ }^{1}$ The general government gross debt reached 78.1 percent of GDP in 2009. Unless a substantial fiscal consolidation is undertaken, the debt is bound to further increase over the medium term (including as a result of population aging), thereby threatening the sustainability of public finances.

\footnotetext{
${ }^{1}$ A previous EDP for France was closed in January 2007. EDPs with all Euro Area countries have also recently been opened.
} 


\section{Box 2. Key Measures Taken by the Government to Support the Economy}

Financial sector measures included the creation of two separate agencies to recapitalize banks and provide government guarantees for bank refinancing:

- Recapitalization has been handled by a $€ 40$ billion ( 2 percent of GDP) bank recapitalization fund (Société de Prise de Participations de l'État, SPPE). It actually injected about half of this amount into the six largest French banks in the form of deeply subordinated debt securities and preference shares with built-in buy-back incentives. In the fall of 2009, banks started to repay the state capital by issuing equity, cooperative certificates or deeply subordinated debt. All but one bank have now repaid the public capital injections.

- Refinancing operations have been undertaken by a $€ 265$ billion (about 14 percent of GDP) bank refinancing scheme (Société de Financement de l'Économie Française, SFEF). SFEF issued government-guaranteed bonds denominated in various currencies and was the largest single issuer of the new asset class, attracting a wide range of investors. It actually raised the equivalent of $€ 77$ billion (about 4 percent of GDP), about 37 percent of which will fall due in 2012. SFEF on-lent to banks in proportion to the market share of each bank in terms of customer loans and assets at a rate that was a function of the funding costs, CDS spreads, and a fee of 20 basis points. French banks started to issue bonds without government guarantees in the summer of 2009 and the bank refinancing scheme was allowed to expire at end-2009.

Fiscal stimulus in the amount of 21/4 percent of GDP over 2009-10 is helping to cushion the downturn and its execution is effectively managed. The package includes a series of cash-flow measures to buttress the corporate sector (tax credits on R\&D outlays, accelerated reimbursement of VAT credits, and accelerated depreciation of investment); actions to support households (a temporary reduction of the personal income tax in 2009, public expenditures on social housing, and additional unemployment benefits); and public investment by the central government, local authorities, and public enterprises. Measures to support the automobile sector, including a car scrapping scheme (prime à la casse), have been very effective in stimulating consumption. In addition, the government has abolished the local business tax (taxe professionelle).

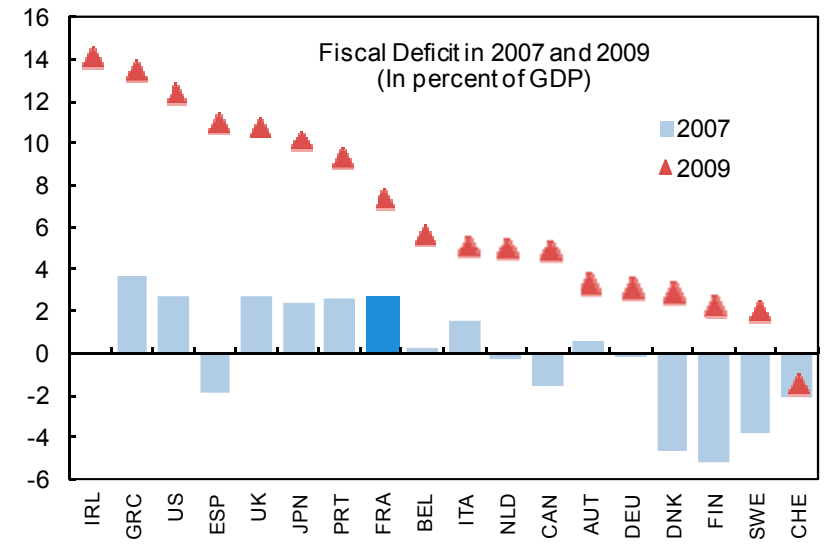

Source: WEO

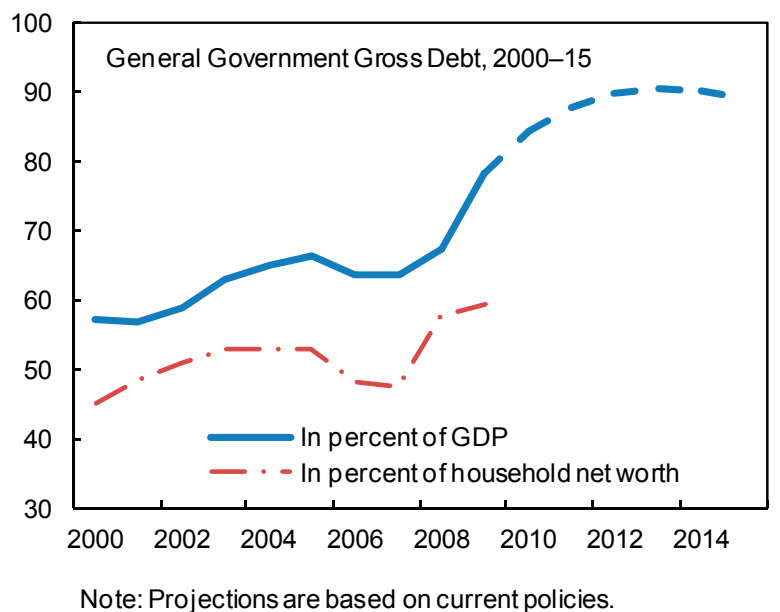


Figure 2. France: Fiscal Developments
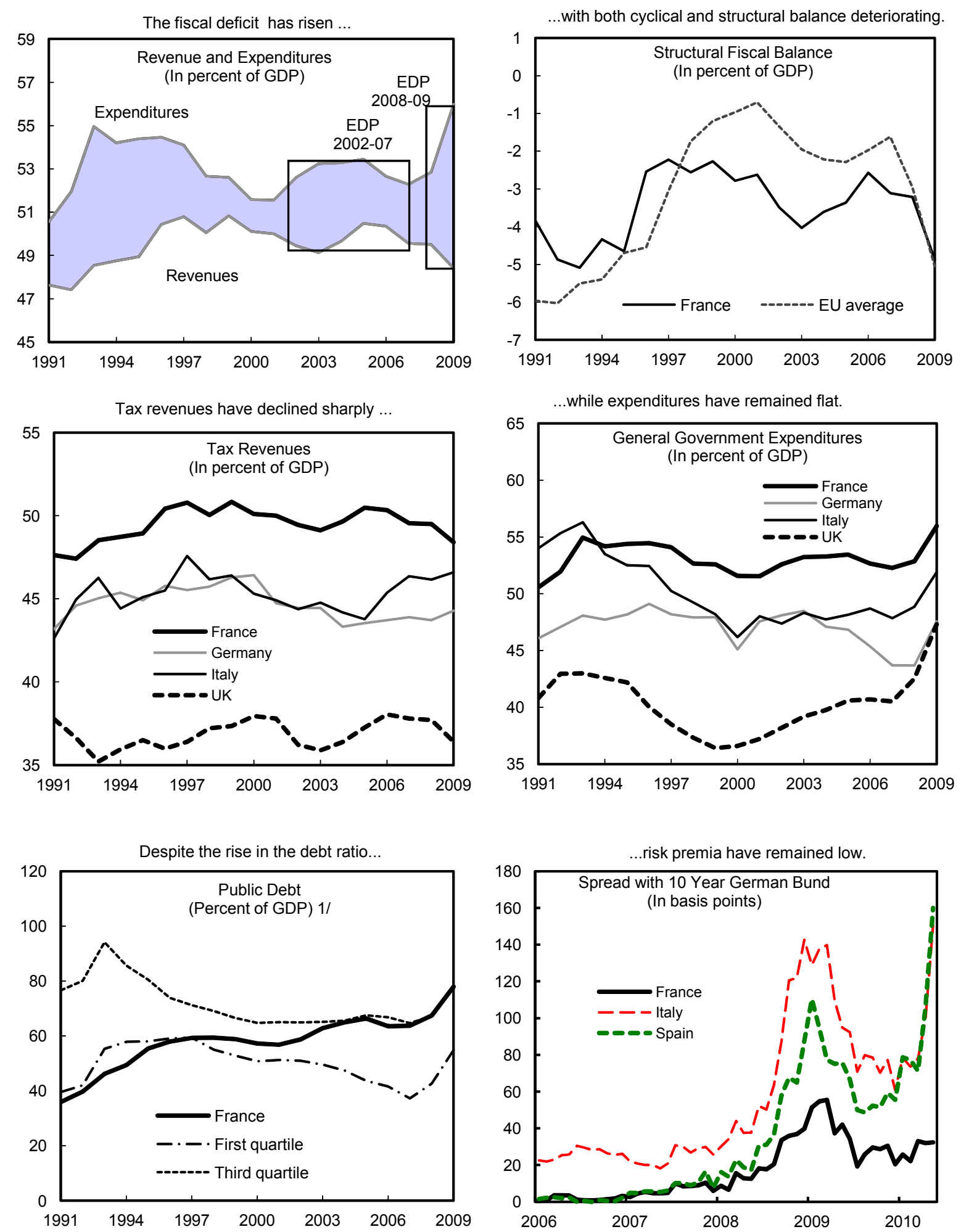

Sources: Eurostat; Datastream; Haver; and IFS.

1/ Sample of twelve EU countries for which full historical data are available, classified by the ratio of debt to GDP in a given year. 


\section{In the financial sector, crisis support measures are being phased out while steps} are being taken to improve the regulatory framework. As stability returned to the French banking sector, a gradual exit from crisis-related financial support proceeded. However, with asset quality weakened by the recession and new threats to financial stability arising from sovereign debt concerns, enhanced vigilance, more transparency, better communication, and effective implementation of newly agreed regulatory guidelines are coming to the policy forefront. With a view to improving financial regulation, the authorities have created a new regulatory and supervisory framework and are playing an active role in international and European financial sector reforms.

\section{Outlook AND Risks: A Gradual Rebound ANd Challenges Ahead}

\section{A. The Recovery is Fragile}

9. France is expected to recover gradually. Staff projects real GDP to grow by 1.4 percent in 2010 and 1.6 percent in 2011, in line with Germany and somewhat faster than in the Euro Area as a whole. The authorities expected a stronger rebound in 2011, assuming a more vigorous recovery in domestic demand. Staff, however, believes that the recovery is likely to be weaker than after previous recessions, due to the global nature of the recent downturn and the damage to financial markets in France and elsewhere (Box 3). In addition, the same features of the French economy that partly shielded it during the recession-large automatic stabilizers, high social protection, and long-standing rigidities in labor and product markets - are also likely to slow the pace of the recovery.
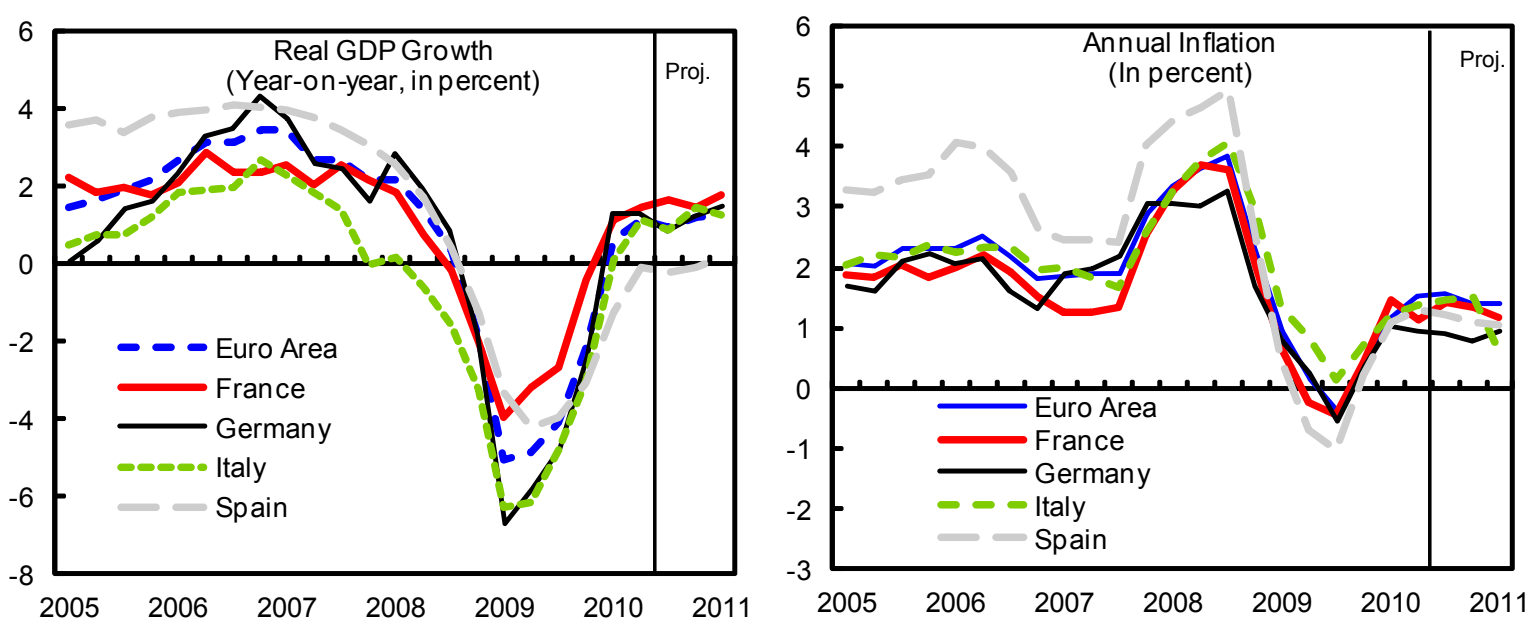

Source: WEO. 


\section{Box 3. The French Recovery in Historical Context}

The French recovery is expected to be somewhat faster than in the Euro Area as a whole. The latest recession has done less damage to the French economy, than to many of its peers in the Euro Area. Indeed, the output loss in France between the pre-recession peak and the trough in early 2009 was about $3 \frac{1}{2}$ percent, compared to over 5 percent in the Euro Area. Staff forecasts that by early 2011 France will recoup about three quarters of this loss, while the Euro Area as a whole will regain less than a half.

However, the current recovery is expected to be slower than comparable past recoveries. There have been only three recessions over the past 50 years that are comparable in scope to the most recent global downturn: the mid-1970s, the early 1980s, and the early 1990s. ${ }^{1 /}$ Of these, the early 1990 s recession was also associated with financial crises in a number of industrial countries, including France. Staff forecasts that the current recovery will be slower than the recoveries from these past recessions both in France and in the Euro Area, owing to the more global nature of the most recent downturn and the more widespread financial distress than in the past.

The current recovery will likely be slow and weak because it follows a global financial crisis. The recoveries following financial crises tend to be weak due to persistently sluggish domestic demand, as households and firms adjust their balance sheets amid lower asset prices and scarce credit. However, countries recovering from financial distress usually benefit from relatively strong external demand, unless their recessions were synchronized with many other countries. In these latter cases, the recoveries tend to be slow mostly because export growth is much weaker than after localized recessions

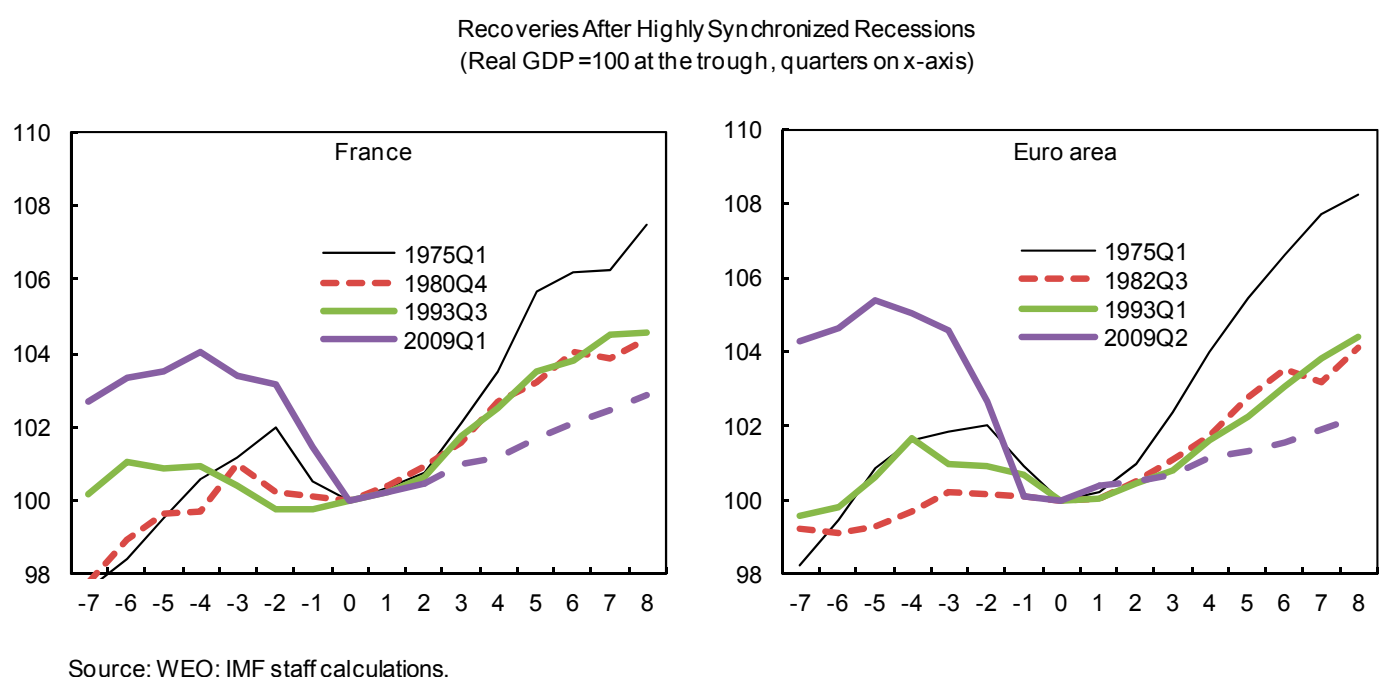

1/ International Monetary Fund (2009), From Recession to Recovery: How Soon and How Strong? World Economic Outlook, April 2009. 
Figure 3. France: A Fragile Recovery
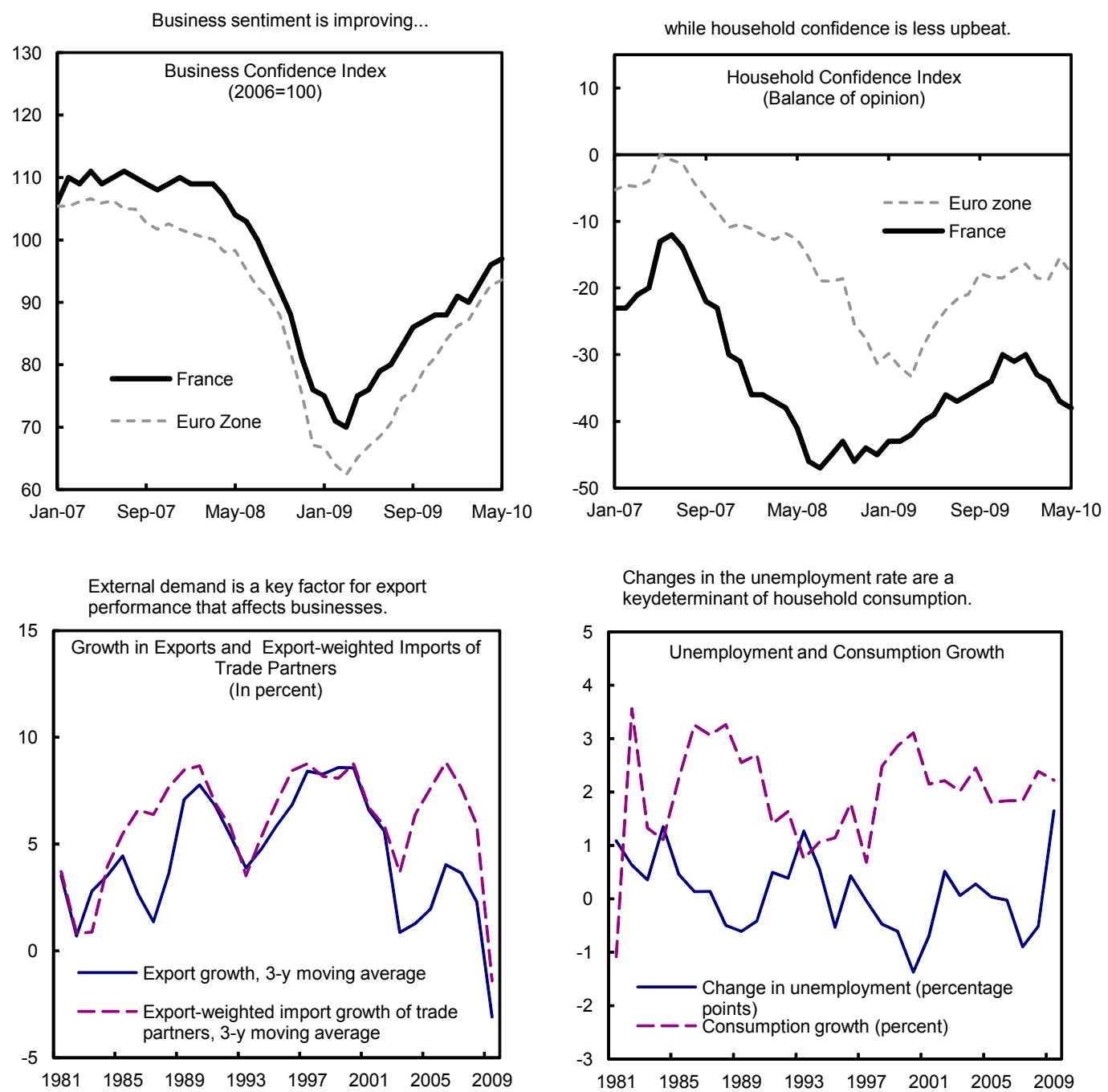

Changes in the unemployment rate are a keydeterminant of household consumption.

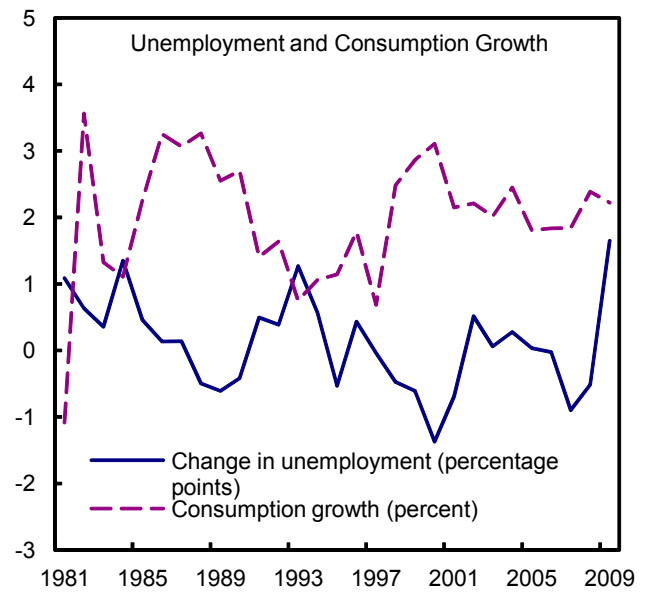

House prices are declining from their peak...
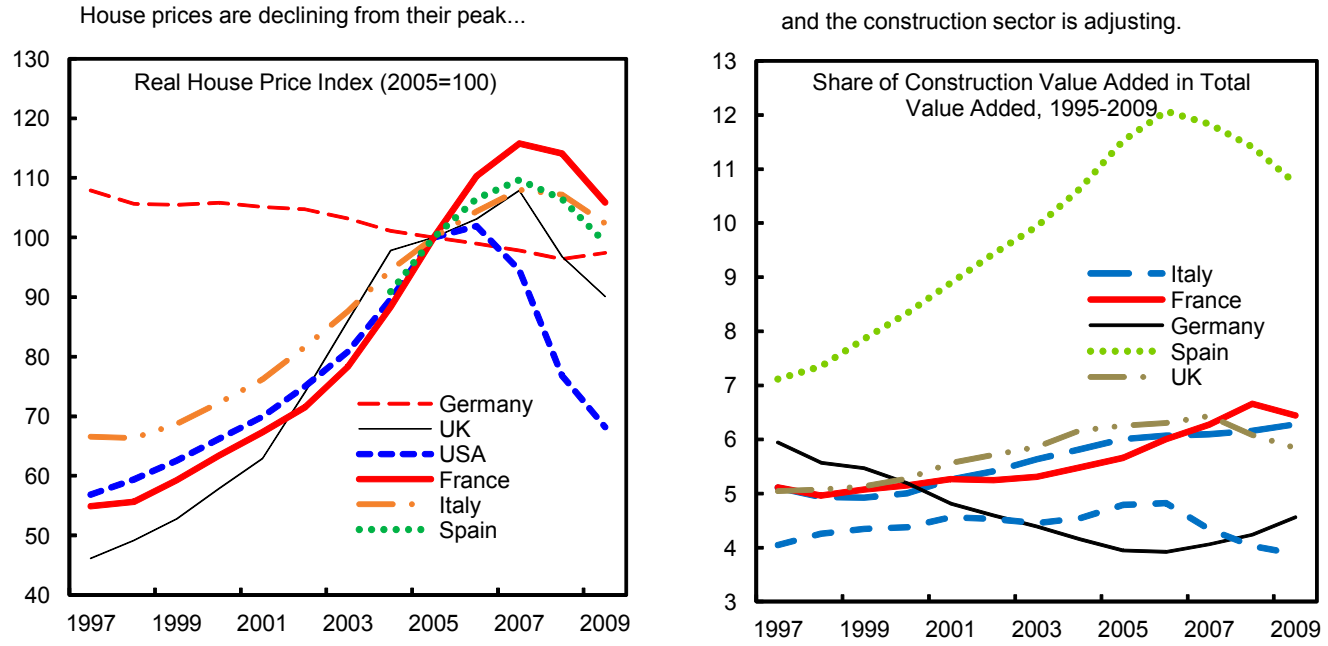

Sources: Global Insight/Datalnsight; Haver Analytics; and IMF, World Economic Outlook. 


\section{The recovery is expected to be driven mainly by domestic demand, with net} exports supportive in the near term. Private consumption growth is expected to pick up somewhat in 2010-11, but the resilience of private consumption will be weakened by high unemployment - forecast at around 10 percent over 2010-11 - with the withdrawal of stimulus measures and prospects of fiscal consolidation adding to caution on the part of households. At the same time, investment will be held back by excess capacity and uncertainty, including about continued credit availability, with residential investment projected to lag business investment as the house price correction continues. Stockbuilding is expected to buttress growth in 2010-11. The export rebound in the first part of 2010 will contribute to output expansion but export growth over the medium term would be limited by the moderate recovery in main trading partners and by competitiveness problems in the French economy, with the depreciation of the euro likely to provide only limited relief. With imports boosted by rising demand, the growth contribution of net exports would turn slightly negative in the medium term. Against this background, and with the impact of recent exchange rate movements partly offset by the dynamics of commodity prices, inflation is forecast to remain low at 1.3 percent in 2010 and 1.6 percent in 2011 , broadly in line with that in the Euro Area.

\section{Staff sees risks to the outlook as slanted to the downside while the authorities} saw them as more balanced. Lingering concerns about sovereign risks in the Euro Area could dampen confidence, increase financing costs, and depress demand. A slower-than-expected recovery in trading partners, linked to the European debt turbulence and intensified fiscal consolidation efforts, would weaken exports. Since roughly half of French exports are destined for the Euro Area and about two-thirds for the European Union, growth prospects there are most important. Risks in the financial sector, linked to the impact of the recession on asset quality and to potential spillovers from mature markets, could further depress credit growth. A sharp decline in housing prices would further weaken the construction sector, which at about $6 \frac{1}{2}$ percent

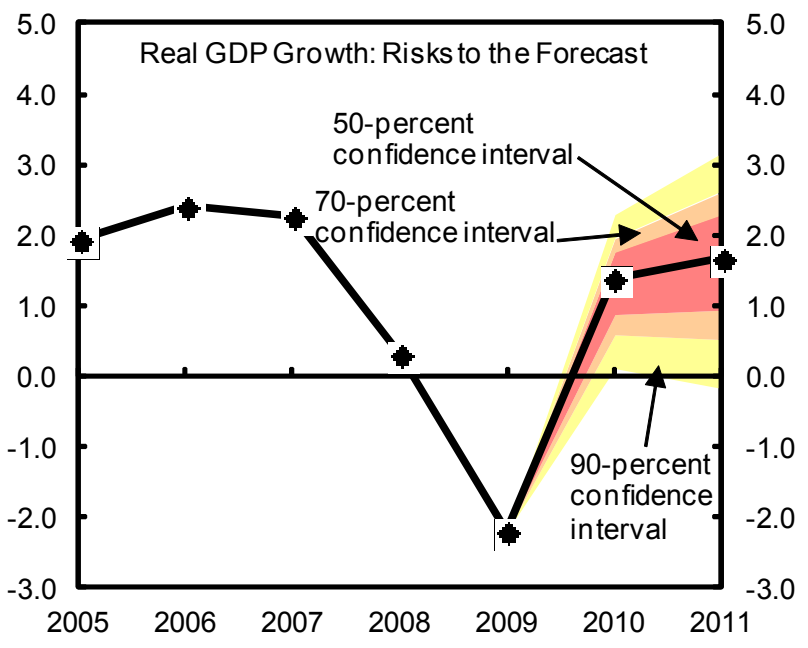

So urces: IMF staff estimates and projections. Notes: The chart includes the following risks to the baseline growth projections in 2010 and 2011: (a) a weakening in foreign demand; (b) a smaller increase in unemployment.; (c) a rise in funding costs; (d) a dep reciation of the euro. The risk assessment is based on the methodology described in the IMF Working Paper WP/09/178 by Selim Elekdag and Prakash Kannan. of GDP is still some 1 percent larger than its historical size. However, the fallout from a house price correction for household consumption would be limited by the relatively low 
level of household indebtedness and the relatively difficult access to mortgage financing. ${ }^{2}$ On the upside, a smaller-than-projected increase in unemployment could strengthen consumption growth and bolster confidence. A further depreciation of the euro could lend additional support to exports. Visible progress in the reform agenda, including fiscal consolidation, financial regulation, and structural measures, would inspire confidence and boost demand.

\section{B. Potential Growth has Fallen}

\section{Potential growth is expected to return to trend over the medium term while the} trend rate would be lower than in the recent past due to demographic factors. Potential growth is expected to remain at about 1 percent in 2010-11 and to gradually return to its trend rate of about $1 \frac{1}{2}$ percent over the medium term. In staff's view, the trend rate would be some $1 / 2$ percent lower than over the last decade owing notably to population aging. The drop in potential growth over 2009-11 is associated with the impact of the recession and financial stress. It is linked to the sharp contraction of investment and the resulting slowdown in capital accumulation, a rise in structural unemployment, and a possible temporary reduction in allocative efficiency that could lower total factor productivity growth. Although potential growth is projected to gradually rebound to its trend rate, the French economy has suffered a permanent loss of about $3 \frac{1}{2}$ percent in the level of potential output. The adjustment to the diminished productive capacity could result in persistently high unemployment going forward. The authorities were more optimistic regarding both the trend growth rate of potential output and the impact of the past recession, mainly reflecting their higher estimate of total factor productivity growth.

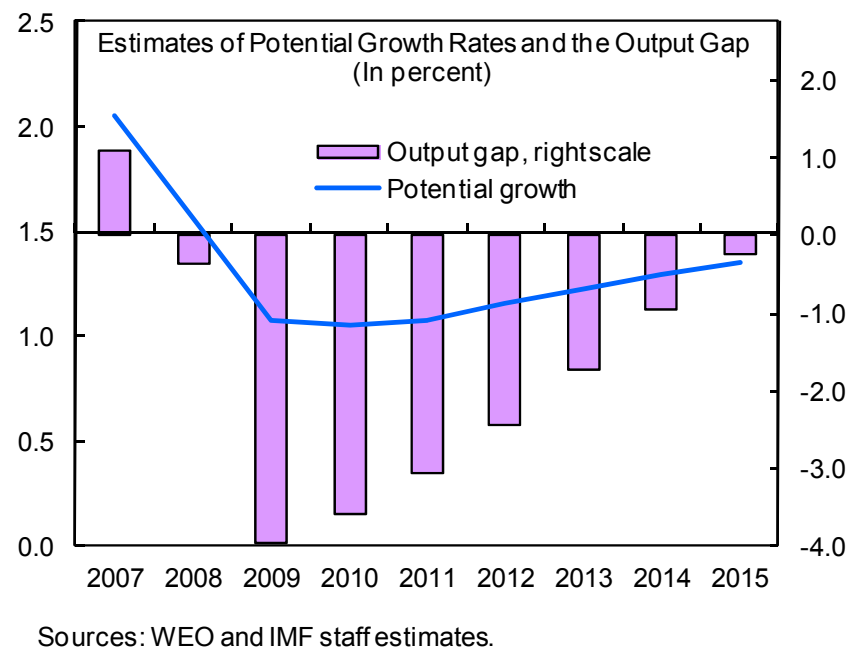

${ }^{2}$ See IMF Country Report No 09/232, July 2009.

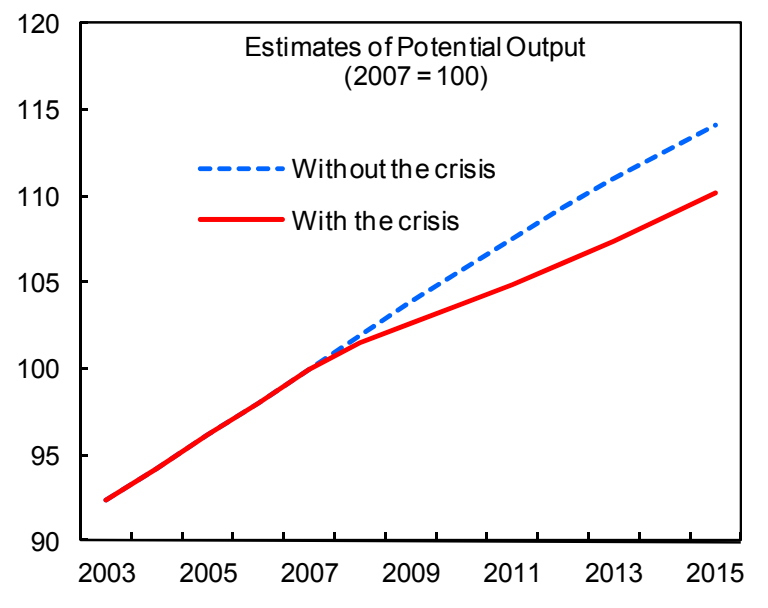




\section{Policy Challenges: Safeguarding Fiscal Sustainability, Ensuring FinANCIAL STABILITY, AND INCREASING GROWTH}

\section{To strengthen the French recovery, key policy challenges lie in the areas of} safeguarding fiscal sustainability, ensuring financial stability, and increasing growth. The authorities have taken important policy actions that have helped to reestablish financial stability and mitigate the impact of the global downturn on the French economy. However, the recession has left significant policy challenges in its wake, key among which are fiscal consolidation, better financial regulation, and structural reforms.

\section{A. Fiscal Sustainability: Achieving a Large and Durable Consolidation}

\section{The fiscal stimulus package that has helped support domestic demand is set to} largely expire by end-2010. The stimulus measures of about $2 \frac{1 / 4}{4}$ percent of GDP enacted in 2009-10 have been mostly front-loaded, diversified, and well-targeted. Good public financial management has helped maintain an appropriate pace of implementation of the stimulus. The amended budget law for 2010 includes additional stimulus of 0.6 percent of GDP from the abolition of the local business tax (taxe professionelle), in order to stimulate business investment, that is only partly offset by other taxes (Box 4), and 0.1 percent of GDP from the new public investment program focused on education and research (investissements d'avenir). The bulk of stimulus measures is set to automatically end in 2010.

\section{The impact of the recession on the fiscal balance has aggravated the challenging} debt situation associated with mounting aging-related spending pressures. Under current policies, the primary balance is set to remain in deficit through 2014 and, as a result, the debt ratio could climb more than 25 percentage points above its pre-crisis level, reaching 90 percent of GDP over the medium term. About two-thirds of the debt buildup between 2007 and 2015 is estimated to come from the automatic stabilizers and the crisis-induced loss of potential output, as well as the crisis-related revenue loss, the cost of the fiscal stimulus package, and financial sector support. The remainder is explained by interest payments and structural deterioration not related to the crisis that would occur without consolidation measures over 2011-15. In the absence of significant policy adjustment, large spending pressures from agingrelated entitlements on health care and pensions threaten to raise the public debt to unsustainable

Debt Decomposition for Advanced G20 Countries and France, 2007-15 (in percent of GDP)

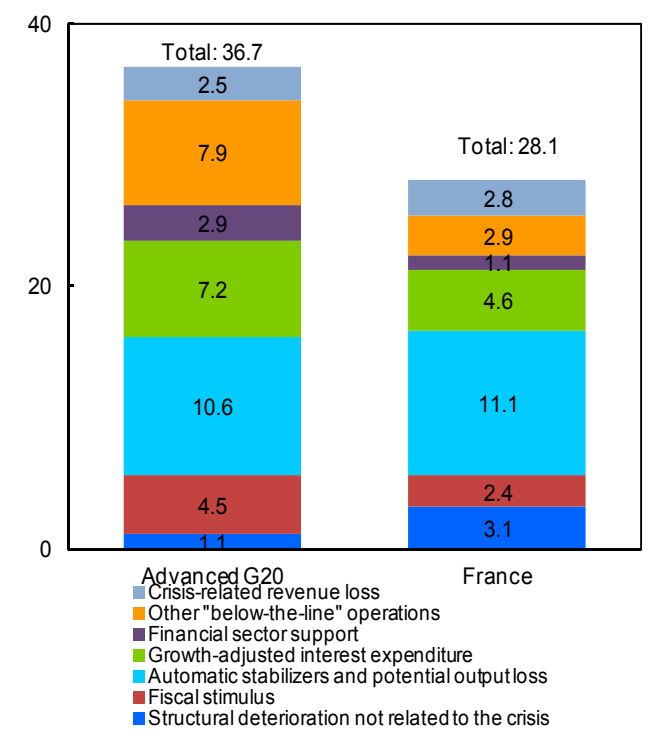

Sources: WEO; IMF staff estimates and projections. levels over the long term. 
France: Projected Pension and Healthcare Expenditures, 2010-50 (in percent of GDP)

\begin{tabular}{lcccccccc}
\hline & & & & & & & \multicolumn{2}{c}{$\begin{array}{c}\text { Change, } \\
2010 \text { to } \\
2030\end{array}$} \\
\hline Pensions & 2010 & 2015 & 2020 & 2025 & 2030 & 2040 & 2050 & 15.7 \\
Healthcare & 13.6 & 14.6 & 14.7 & 15.3 & 15.6 & 15.8 & 14.6 & 3.5 \\
\hline
\end{tabular}

Sources: From Stimulus to Consolidation: Revenue and Expenditure Policies in Advanced and Emerging Economies, IMF Policy Paper, April 2010 and Conseil d'Orientation des Retrailes, Eighth Report, April 2010.

\section{Box 4. The 2010 Local Business Tax Reform in France}

Beginning in 2010, the government suppressed the controversial local business tax (taxe professionnelle, TP), as part of the stimulus measures targeted at boosting competitiveness and growth, especially for SMEs. The TP used to be levied on the value of the fixed asset base of companies, namely property (that will still be taxed but under a different name) and capital equipment (abolished). As a result, investment suffered, especially in industry, energy and transport sectors, which contributed about two-thirds of the total revenues generated by the tax. Over the past years, the government had already made some concessions to certain types of business, exempting artisans, farmers as well as rural and urban development zones, introduced an exemption for new capital investment, and added a cap on tax increases for larger companies.

TP was one of three local taxes that funded local government services in France. In 2007, TP amounted to 1.5 percent of GDP, as compared to the respective revenues of 1.1 and 0.8 percent of GDP from the property tax (the taxe foncière, TF) and the residence tax (the the taxe d'habitation (TH). The proceeds from TP were split between local governments ( 0.9 percent of GDP, of which about 0.3 percent came from the central government to substitute for TP exonerations), departments ( 0.45 percent of GDP), and regions (the remaining 0.1 percent of GDP). TP came under fire for its poor horizontal redistribution properties as it favored more industrialized jurisdictions, for some of which it accounted for up to 80 percent of total revenues.

The central government pledged to shelter the local governments from any revenue loss due to TP reform. After being compensated in 2010, local authorities will be assigned revenues from several other taxes, many with a less volatile base than capital investment under TP. In particular, the TP revenue loss is expected to be offset by a combination of quotas from the property tax on enterprises (the cotisation foncière des enterprises, CFE) and VAT (the cotisation sur la valeur ajoutée des enterprises, CVAE). The CVAE progressive rates will range from zero to 1.5 percent, depending on turnover. Large energy, telecommunications, and railway companies will pay an additional lump-sum levy. For the central government, the losses are projected to phase out gradually, in line with the widening tax base for the corporate income tax.

16. The government is firmly committed to undertaking a large fiscal consolidation starting in 2011, which staff supports. France's Stability Program 2010-13 aims to reduce the deficit to 3 percent of GDP by 2013, and important steps have been taken to increase the national ownership of the targeted consolidation, including by further strengthening the multiyear budgetary framework for 2011-13. Pursuant a national conference on the public deficit, a number of working groups are suggesting ways to re-establish equilibrium in public 
finances in France, encompassing all levels of government. In June, a major pension reform was announced that is to be legislated in the coming months (see below). Already announced revenue measures include gradually offsetting the revenue loss due to the abolishment of the local business tax and reducing the numerous tax expenditures (by $€ 5$ billion during 201112 , to reach the total of $€ 6$ billion in 2013). The proposed ban on introducing new tax expenditures and exonerations from social security contributions outside the budgetary process would mark encouraging progress in improving fiscal discipline. On the expenditure side, the announced measures envisage increased efforts of the central government, including continued personnel reduction (replacing only one in two retiring civil servants) and a nominal spending freeze, also applicable to transfers to the local governments, but excluding interest and pension outlays.

\section{Overall, the recently announced fiscal measures, provided these are legislated} and implemented, are sizeable and ensure that all levels of government participate in fiscal consolidation. The table below quantifies the announcements in terms of their impact on revenues and expenditures. Key efforts will come from spending freezes and cuts at the central government level and from the pension reform package. For local governments, the freeze on central government transfers is very important to improve spending discipline.

France: Announced Fiscal Measures, 2011-13

\begin{tabular}{lcc}
\hline & \multicolumn{2}{c}{$\begin{array}{c}\text { Total for 2011-13 } \\
\text { in billion } \\
\text { euros }\end{array}$} \\
$\begin{array}{c}\text { in percent of } \\
\text { 2010 GDP }\end{array}$ \\
\hline Withdrawal of fiscal stimulus & 9.6 & 0.5 \\
Reduced compensation to local governments for the 2010 local business tax reform & 6.0 & 0.3 \\
Announced freezes and cuts 1/ & 10.0 & 0.5 \\
Reduction of tax expenditures & 6.0 & 0.3 \\
Reducing healthcare spending norm & 2.4 & 0.1 \\
Pension reform 2/ & 20.8 & 1.1 \\
Reduction of exemptions on social security contributions 2/ & 3.0 & 0.2 \\
Total announced measures & 54.8 & 2.8 \\
\hline
\end{tabular}

Sources: French authorities and IMF staff estimates.

$1 /$ Includes freezing of the salary grid for the public servants, transfers to local governments, and the moratorium on new off-budget tax expenditures.

2/ Measures yet to be legislated.

18. The announced fiscal package contains a range of necessary elements but further efforts are needed to achieve the envisaged consolidation beyond 2011. The government's consolidation program is based on the overly optimistic assumption that annual growth will increase to $2 \frac{1}{2}$ percent in 2011-13. The authorities indicated that they are in the process of revising their growth projections and saw merit in staff's advice of developing a set of contingency spending measures in case economic developments turn out worse than projected. The baseline scenario, that is built on staff's macroeconomic projections and excludes measures that still need to be legislated, shows that the overall deficit would appropriately decline to about 6 percent of GDP in 2011, but remain at about 4 percent of GDP by 2013. A debt sustainability analysis shows a debt ratio that would 
remain well above the Maastricht threshold even in good times, but that could reach over 110 percent of GDP in case of adverse shocks. ${ }^{3}$ Further efforts would be required to reduce the overall deficit to the target of 3 percent of GDP by 2013, as illustrated in the consolidation scenario. Such additional efforts should aim to limit detrimental effects on growth and include implementation of the announced reform of the pension system; implementation of effective spending ceilings in health care, taking account of the complicated publicprivate ownership structure of the health insurance system; and strict containment of local government spending. In parallel, broadening the VAT and the CIT bases as well as the introduction of a carbon tax

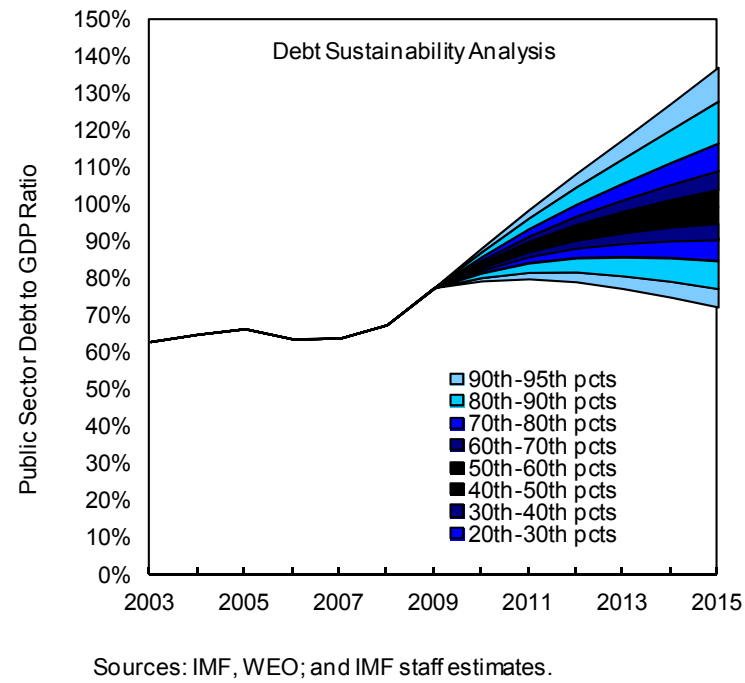
coordinated at the European level would be important.

France: Fiscal Scenarios, 2009-15 (in percent of GDP)

\begin{tabular}{lrrrrrrr}
\hline & 2009 & 2010 & 2011 & 2012 & 2013 & 2014 & 2015 \\
\hline Baseline scenario & & & & & & & \\
General government balance & -7.5 & -8.0 & -6.1 & -4.8 & -3.9 & -3.2 & -2.4 \\
Primary balance & -5.2 & -5.4 & -3.3 & -1.9 & -1.0 & -0.1 & 0.7 \\
Structural balance & -5.0 & -4.9 & -3.7 & -3.0 & -2.6 & -2.4 & -2.0 \\
General government gross debt & 78.1 & 84.3 & 87.8 & 89.7 & 90.3 & 90.1 & 89.1 \\
Real GDP growth & -2.5 & 1.4 & 1.6 & 1.8 & 2.0 & 2.1 & 2.1 \\
& & & & & & & \\
Consolidation scenario & & & & & & & \\
General government balance & -7.5 & -8.0 & -6.0 & -4.4 & -3.0 & -2.1 & -1.1 \\
Primary balance & -5.1 & -5.4 & -3.2 & -1.5 & -0.1 & 0.9 & 1.9 \\
Structural balance & -5.0 & -4.9 & -3.5 & -2.4 & -1.4 & -0.9 & -0.3 \\
General government gross debt & 78.1 & 84.3 & 87.8 & 89.4 & 89.4 & 88.2 & 86.0 \\
Real GDP growth & -2.5 & 1.4 & 1.6 & 1.6 & 1.7 & 2.0 & 2.0 \\
\hline
\end{tabular}

Source: IMF staff estimates and projections.

\section{A major pension reform has recently been announced as a key part of the} authorities' strategy to control social spending over the medium term. On June 16, the details were unveiled of the proposed reform, which aims to achieve financial equilibrium in the pension system by 2018 from a current deficit of almost 1.5 percent of GDP. In particular, the reform would gradually increase the effective retirement age by simultaneously raising the legal retirement age from 60 to 62 years and the legal minimum age of full pension entitlement from 65 to 67 years; raise high-income pension

\footnotetext{
${ }^{3}$ See IMF SPN/09/18 for a detailed description of the methodology.
} 
contributions; and gradually align the pension system of civil servants with that of the private sector. In parallel, resulting from previous reforms, the contribution period is being lengthened to reach 41 years in 2012 (Box 5). The reform is expected to provide a tangible increase in the effective retirement age, currently among the lowest among OECD countries. This will allow for better synchronizing the retirement policies with life expectancy at retirement, which at 28 years for women and 24 for men is the longest among advanced countries. In healthcare, significant reforms are needed to contain spending, in order to put the healthcare system on a solid financial footing and reduce its persistent deficits. A number of proposed measures aim to limit hospital and drugs costs and to better enforce the planned reduction of the existing spending norm (ONDAM), but significantly more needs to be done. ${ }^{4}$

\section{Box 5. The Pension System in France}

France's compulsory pay-as-you-go pension system, one of the oldest in Europe, is also one of the most generous. Currently, about a quarter of the French population (16 million people) receives pensions that total 13.5 percent of GDP. France tops the list of advanced countries with respect to the share of pensions financed by public transfers (over 85 percent). Since 2006, France has started to feel the demographic effect of aging, adding 280 thousand new retirees every year. The contribution ratio is projected to continue its decline from an already low 1.8 workers per retiree in 2010 to 1.2 by 2050 , in spite of the highest birth rates in Europe. The system is fragmented between over 30 different schemes with public employees in particular enjoying higher pension benefits than their counterparts in

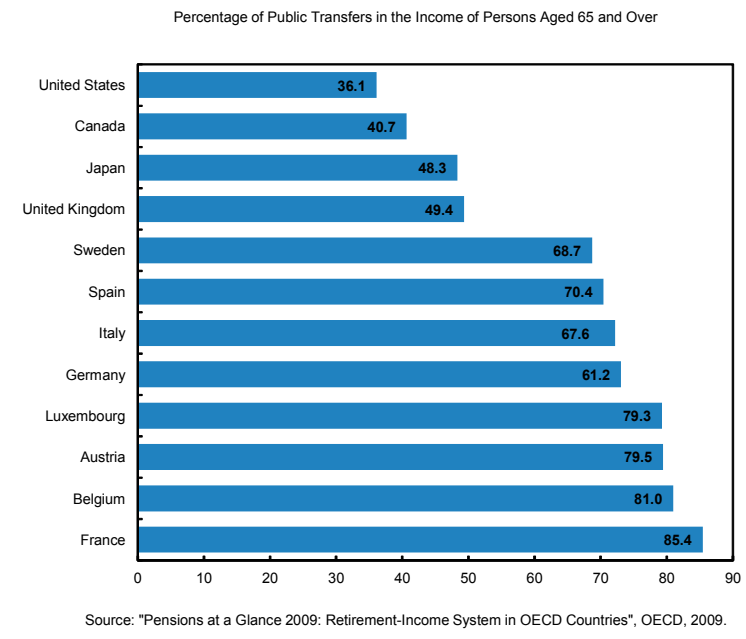
the private sector, a situation the government wants to alter.

Previous reform efforts in France succeeded in changing the parameters of the system, though at a significant cost, including lengthy periods of social unrest. During 1985-91, the government raised the employees' contribution rates from 4.7 to 6.55 percent. The 1993 reform increased the base wage for calculating pensions in the private sector from the top 10 years to the top 25 years. Subsequent attempts have only brought limited cost-savings. The 2003 reform aimed at linking the contribution years for a full pension to life expectancy. The minimum contribution period for a full pension was increased from 37.5 to 40 years and, gradually, to 41 years by 2012 and 41.5 years by 2020 . The 2007 reform extended the increase in contribution period to pensions under special regimes. These reforms will continue under the current reform effort.

\footnotetext{
${ }^{4}$ A working group has outlined a number of detailed recommendations.
} 
20. Efforts to control local government spending are underway but need to be decisively maintained over the medium term. The significant decentralization efforts between 1990 and 2004 brought rapid growth of local government spending that averaged above 8 percent per year in real terms during the past decade, bolstered by increasing transfers from the central government. The authorities pointed out that freezing central government transfers to local governments in nominal terms over 2011-13 will encourage efficiency gains, including by reducing the duplication of responsibilities for each of the four layers of the local government. The latter could be accomplished by mimicking the central government policy of not replacing some retiring civil servants at the departmental and regional levels. The recent local business tax reform, combined with efforts to increase transparency and accountability, including by tying future increases in the local tax burden on firms to those on households, are welcome steps.

\section{A sizable consolidation requires strengthening of the credibility and full} national ownership of the medium-term consolidation objectives. Based on the experience from previous fiscal consolidations in France and elsewhere, successful adjustments usually rely on credible, comprehensive multi-year budgetary frameworks (see Analytical Note 2). The authorities concurred that to support the current consolidation plan the formal fiscal framework needs to be extended beyond the central government to encompass the local governments and the social security systems. To enhance credibility, the multiyear budget should rely on realistic independent macroeconomic forecasts (Box 6). The authorities are considering setting up a council to validate the macroeconomic assumptions underlying the multiyear budget.

\section{Introducing a fiscal rule would significantly strengthen the credibility of the} consolidation and support better fiscal discipline in the Euro Area. A high-level working group is examining the modalities of a possible fiscal rule and will present its recommendations by end-June. ${ }^{5}$ The authorities indicated their desire to have a rule that is tailored to France-specific circumstances, notably as regards the coordination of the contribution of the different levels of government to the implementation of the rule. Staff encouraged the authorities to adopt, like others European countries, a fiscal rule on the structural government balance, preferably with a built-in debt-brake mechanism. To be credible, the rule should be enshrined in high-level legislation (e.g., either the Constitution or a loi organique). With a further large EU member following this route, the step would constitute a de facto strengthening of the implementation of the Stability and Growth Pact and boost fiscal discipline in the Euro Area.

\footnotetext{
${ }^{5}$ The working group is chaired by former IMF Managing Director Camdessus and comprises high-ranking officials, parliamentarians, and leading French and other European academics.
} 


\section{Box 6. Strengthening Macroeconomic Assumptions for Multiyear Budgets}

Multiyear macroeconomic forecasts done by the budget-preparing entities tend to be systematically biased upwards for the outer years. This bias has been present, in particular, in the Stability Programs submitted annually by members of the Euro Area. A recent study by the European Commission found substantial positive forecast errors in growth assumptions underlying fiscal projections one year ahead in a number of countries (see table).

More realistic forecasts can be obtained by a fully independent forecasting body or through validation of the government's forecast by an independent council. Examples of the first approach include the Netherlands, Belgium, Austria, Canada, the US, and, since very recently, the UK. As for the second approach, the references are Sweden, Hungary, Germany, and Japan. There is considerable variation in the extent to

Average Forecast Errors, Official GDP Growth (projections one year ahead (1987-2004))

\begin{tabular}{ll}
\hline Germany & $0.61^{*}$ \\
France & $0.42^{*}$ \\
Italy & $0.76^{*}$ \\
Belgium & 0.30 \\
Austria & 0.10 \\
Netherlands & 0.18 \\
\hline
\end{tabular}

Sources: European Commission (2004), Economic Papers No. 210.

* Defines estimates significantly different from zero at the 10 percent significance level. which an independent agency of either type is expected to analyze current fiscal developments and the costs of budgetary initiatives. However, the existence of an independent agency of either type helps make the forecasts of the relevant macroeconomic variables more realistic.

Country experiences include the Central Planning Bureau (CPB) of the Netherlands which conducts detailed analyses and provides the economic assumptions for the budget. It also undertakes research on a broad range of economic issues and plays a key role in the development of the fiscal policy contained in the agreements among the government coalition partners. The U.S. Congressional Budget Office (CBO) advises Congress on a range of fiscal issues. It analyzes the administration's budget based on its own assumptions, "scores" new legislative proposals, and produces a large number and variety of in-depth analyses and reports. In Canada, budgets are based on macroeconomic assumptions averaged across the lower bound of the private forecasters' consensus. In Chile, to strengthen the implementation of the structural fiscal rule, the projection of inputs needed for estimating the trend GDP and "trend" copper prices is delegated to two independent expert panels.

\section{B. Financial Stability: Towards a Safer and More Resilient Financial Sector}

\section{French banks are emerging relatively stronger from the global financial crisis and a gradual exit from crisis-related financial support is under way. Staff and} authorities agreed that the response the financial crisis had been successful. The refinancing scheme was allowed to expire at end-2009, and BPCE (see below) is the only bank still retaining some state capital. Driven by rising revenues across business lines (including retail, corporate and investment banking) and good control over operating expenses, gross operating profits of major French banks surged from $€ 25$ billion in 2008 to about $€ 45$ billion in 2009, in part reflecting low refinancing costs at the ECB. Despite the increase in the cost of risk, all major banks registered rising net profits and the rate of return on equity rose by two percentage points to above 6 percent in 2009. Retained earnings, equity issuances and a reduction of risk weighted assets, helped increase Tier 1 capital ratios from 8.7 in 2008 to 10.2 in 2009, above the Euro Area average of 9.1. 


\section{The crisis-related mergers in the financial sector increased the systemic} importance of major institutions. A high level of concentration and significant crossownership among financial institutions - including between banks and insurance companies ("bank assurance") — have been long-standing characteristics of the French financial system. As a result of the crisis, this feature became more dominant, given that domestic and crossborder consolidation has been one of the responses to address financial sector problems. Specifically, the acquisition by BNP Paribas of Fortis Banque in Belgium and Luxembourg and the merger of Groupe Caisse d'Épargne (GCE) and Groupe Banque Populaire (GBP) to create BPCE made the sector more dominated by systemically important financial institutions (SIFIs).

\section{The new supervisory structure responds to the need for systemic supervision} while control over remuneration aims to reduce incentives for excessive risk taking. The new Autorité de Contrôle Prudentiel (ACP) introduced in early 2010 merges banking and insurance supervision, licensing, and consumer protection. Staff and authorities agreed that a unified agency can more effectively control risks arising from cross-ownership and the systemic implications of the large entities active in different sectors. The responsibilities of the Autorité des Marchés Financiers (AMF) now include all markets and products as well as consumer protection, and a risk committee has been added. The reform will be completed by the planned creation of a systemic risk board (Conseil de Régulation Financière et du Risque Systémique), with participation of all relevant supervisors and government bodies. This body will also be linked to the European Systemic Risk Board to be established at the ECB. The authorities introduced one-time taxes on bonuses granted in 2009, and implemented G20 recommendations for sound compensation practices. France, along with other EU countries, is planning to impose a financial levy to protect taxpayers from the costs of future potential financial crises.

\section{The fragile recovery and possible spillovers from the European sovereign debt} crisis are now putting renewed stress on the financial system. As a result of the recession, asset quality has worsened, and large exposures of the French financial system to Southern Europe have raised concerns about spillovers and contagion (Box 7). On asset quality, nonperforming loans increased to 3.8 percent of the total loan portfolio in 2010:Q1. Staff expressed concern that the slow and fragile recovery may lead to further pressures on loan quality and banking income, and require additional provisions. With interest rates and exceptional liquidity conditions normalizing and competition returning, corporate and investment banking revenues are unlikely to be sustained at their 2009 level. Additional writedowns on portfolios of risky assets, including commercial real estate, legacy troubled and illiquid securities, and leveraged buy-outs (LBOs), are likely to continue, although at a lower rate than before. Fears of negative spillovers to French banks and insurance companies from the recession and sovereign debt problems in Southern Europe could have a negative impact on performance and outlook; they have already led to significant losses in market 


\section{Box 7. Exposures of French Banks to Greece, Ireland, Italy, Portugal, and Spain (EA5)}

France has diversified exposures to other European countries, including the EA5. Based on the latest BIS data, French bank exposures to EA5 account for about 7 percent of bank assets and 30 percent of nominal GDP. Of the French exposures to EA5 countries, 15 percent are to Greece, Ireland, and Portugal, while 60 percent are to Italy and 25 percent to Spain. The BIS data comprise of holdings of government debt, interbank loans, equity shares, and subsidiaries in EA5 countries. French banks published their exposures to Greece.

Exposures of French banks to EA5 are dominated by claims on nonfinancial corporates. The sector breakdown shows that about half of the exposures are accounted for by claims on corporates and a third are accounted for by holdings of government securities. The breakdown varies by individual countries with exposures to Italy's public and corporate sector being the highest among public and corporate exposures to EA5 countries and exposures to Spain's financial sector being the highest among exposures to banks in EA5 countries.

The direct impact on French banks of the Greek debt crisis is likely to be manageable. The two French banks most exposed to Greece gain substantial exposures mostly through the loan books in their Greek subsidiaries, which are small in comparison with the size of the respective French parent banks. Individual French banks' exposures to Greece, Portugal, and Spain range from 2 to 10 percent of equity, compared with about 70 percent of large European banks having exposures above 10 percent of equity and the largest one having exposures of over several times of equity. The counterparty risk and funding risk of French banks may increase consequently, but given the dominance of corporate loans, the direct impact will depend to a large extent on the depth of the recession in these countries.

However, French banks remain vulnerable to spillovers. The foreign exposures of French banks tilt toward mature markets. Exposure to mature markets represented 83 percent of total foreign claims in 2009, dominated by exposures to Belgium, Germany, the U.S., and the U.K. France would be vulnerable to spillovers from these countries too if they were to be affected in the first place, which would significantly weaken the capital and liquidity position of the banks.
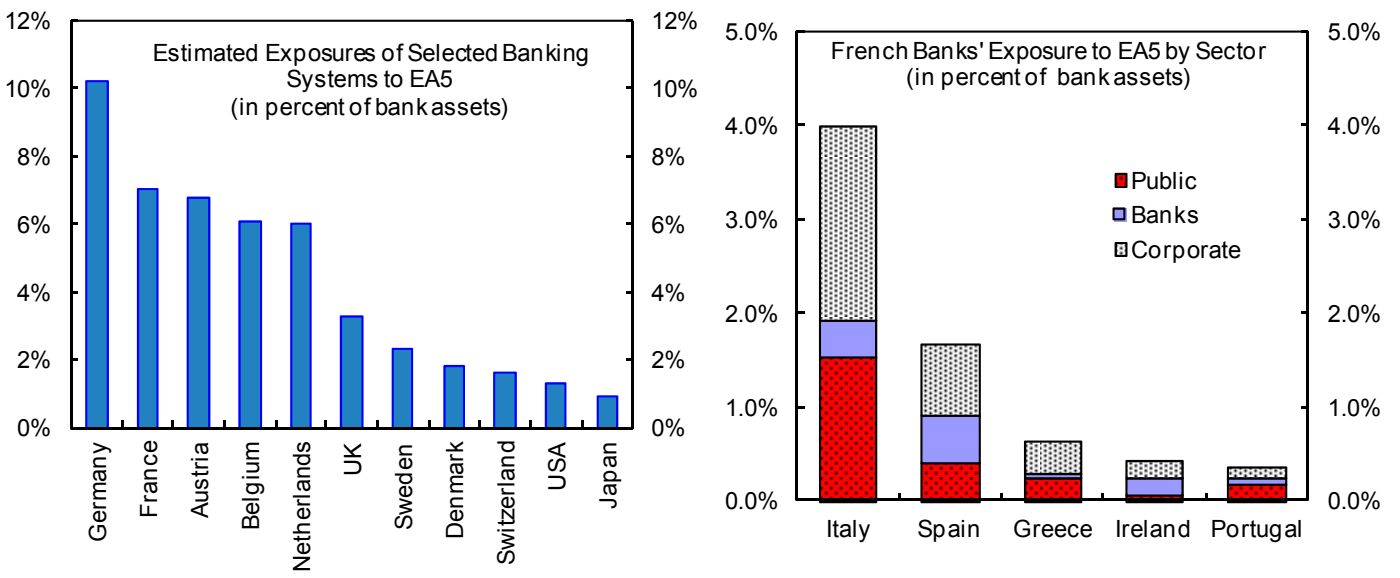

Sources: BIS, BdF, and Fund staff estimates.

valuation, and contributed to the difficulties in medium and longer term funding. Spillovers of potential financial sector stress in France could imply reduced lending in Central and Eastern Europe. 
27. As a result of spillovers, funding pressures could intensify. The funding environment for all banks in Europe is difficult: they face high rollover needs, competition for funding from much higher sovereign issuances, the expected withdrawal of extensive liquidity support from the ECB, and more competition for deposits to meet new liquidity requirements. French banks rely considerably on wholesale funding and have increased their reliance on ECB longer-term funding over recent quarters, although their share remained lower than their weight in the Euro Area banking sector. Banks have to either find ways to renew their funding, extend maturities, issue more long-term debt, build stronger liquidity buffers, or deleverage from the funding side. Staff noted that in addition to pressures common to all European banks, French banks might suffer from the perceived risks of their comparatively larger exposures to Southern Europe, which could reduce access and increase costs of funding, especially in US dollars. The authorities felt that the diversified nature of the exposures of the financial sector across different Southern European countries, including both sovereign and commercial debt, would limit potential fallout. Nevertheless, reactivating the government-supported bank refinancing scheme may be considered if needed as well as continuing with the bank recapitalization scheme, in case banks are unable to raise sufficient capital to fully address a shortfall should this be revealed by the ongoing stress tests.

\section{More transparency and better communication may help market assessment of}

the French financial system. Staff argued that publication of stress tests and greater transparency on country exposures could be confidence enhancing. While seeing merit in the publication of the stress tests coordinated by the Committee of European Banking Supervisors (CEBS), the authorities were concerned that certain types of stress testsparticularly those testing resilience to sovereign risk - could put in question the credibility of the European response to the ongoing crisis. ${ }^{6}$ Staff noted that appropriate and coordinated disclosure of key exposures, preferably at the European level, could also provide better guidance to markets than publicly available but possibly misleading information. More frequent publication of supervisory data on financial soundness, including developments in nonperforming loans, would also be helpful.

\section{France actively supports international financial regulatory reform but has} raised concerns that elements of the proposals might impose excessively high costs. The authorities have participated in the expert groups and discussions of the Basel Committee on Banking Supervision (BCBS) and CEBS on enhanced capital and liquidity requirements. They have also contributed to the regulation of over-the-counter derivatives markets along with the AMF and to the design of an EU framework for crisis management and resolution of cross-border financial institutions along with the US Treasury. While fully supporting the aims of the regulatory reform proposals for banks and insurance companies, the authorities

\footnotetext{
${ }^{6}$ After the mission, the EU announced the publication of the stress tests results in July.
} 
raised concerns that Basel III might require substantial additional capital for integrated financial systems such as those in France. If implemented without further adaptations, it could lower lending and depress growth. Staff noted that these reforms remain to be fully defined and urged France to actively participate in ongoing macroeconomic impact studies and follow-up work to refine the reform proposals.

\section{Increasing Growth: Modernizing the Economic Structure}

\section{The output losses from the crisis require a renewed and more effective}

emphasis on measures to raise competitiveness, in order to enable France to benefit more from the rebound in global trade. Like most advanced economies, France has experienced a marked deterioration in export performance over the last decade, with the current account balance deteriorating and foreign market shares sliding (Figure 4). Although the overall exchange rate assessment based on the CGER methodologies does not suggest disequilibrium, the overvaluation of the Real Effective Exchange Rate (REER), driven in part by the dynamics of the euro, points to a lack of competitiveness in global markets. The recent depreciation of the euro would help strengthen competitiveness vis-à-vis outside the Euro Area. Within the Euro Area, there is a widening competitiveness gap, in particular related to diverging unit labor costs, with the best performers, which are France's principal competitors in the global market. The current boon to French competitiveness from a sharp increase in unit labor costs in a number of France's trading partners is likely to be temporary, as short-time work schemes in these countries are being phased out. In addition, supply rigidities in responding to changing global demand have also played an important role in hampering export performance. Restoring competitiveness will require policies to encourage wage moderation, foster research and development, promote innovation, improve competition, and create favorable conditions for businesses to grow (see Analytical Note 3).

Estimates Applying the CGER Methodology 1/

\begin{tabular}{|c|c|c|c|c|c|}
\hline & \multicolumn{2}{|c|}{ France } & \multirow[t]{2}{*}{ Euro area } & \multirow[t]{2}{*}{ Germany } & \multirow[t]{2}{*}{ Italy } \\
\hline & $\begin{array}{c}\text { Current } \\
\text { estimate } \\
\text { (April, 2010) }\end{array}$ & $\begin{array}{c}\text { Previous } \\
\text { Article IV } \\
\text { (April, 2009) }\end{array}$ & & & \\
\hline Current account norm (macro balance) & -7 & -6 & 2 & -4 & 9 \\
\hline Equilibrium exchange rate (EREER) & 7 & 4 & 12 & -2 & 7 \\
\hline NFA stabilizing (External sustainability) & 1 & 9 & 2 & -9 & 8 \\
\hline Average & 0 & 2 & 5 & -5 & 8 \\
\hline
\end{tabular}

Source: IMF staff estimates.

1/ Positive number indicates that REER is above equilibrium. 
Figure 4. France: Competitiveness and External Performance
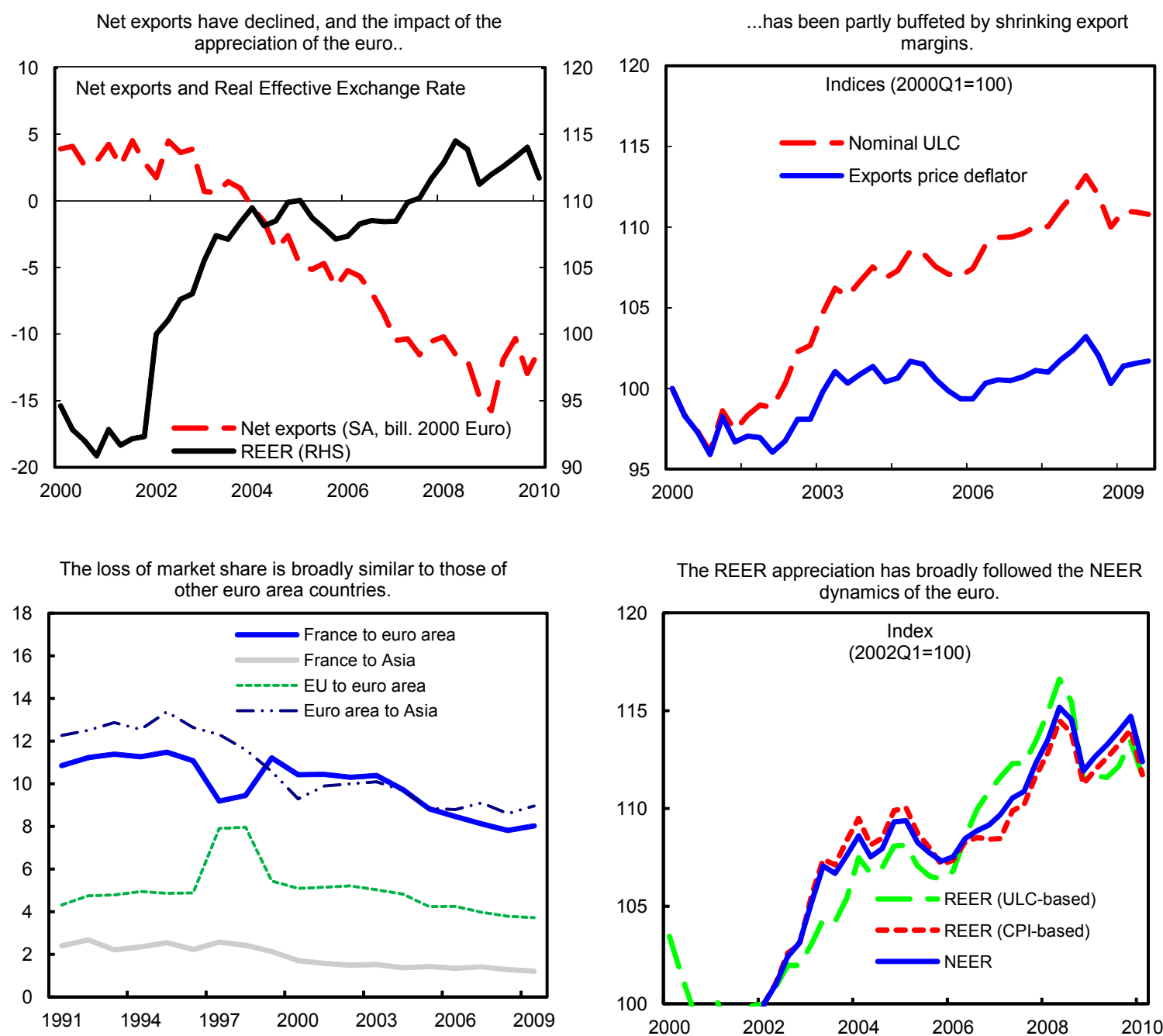

Labor cost growth in France remains higher than in its main trading partners.
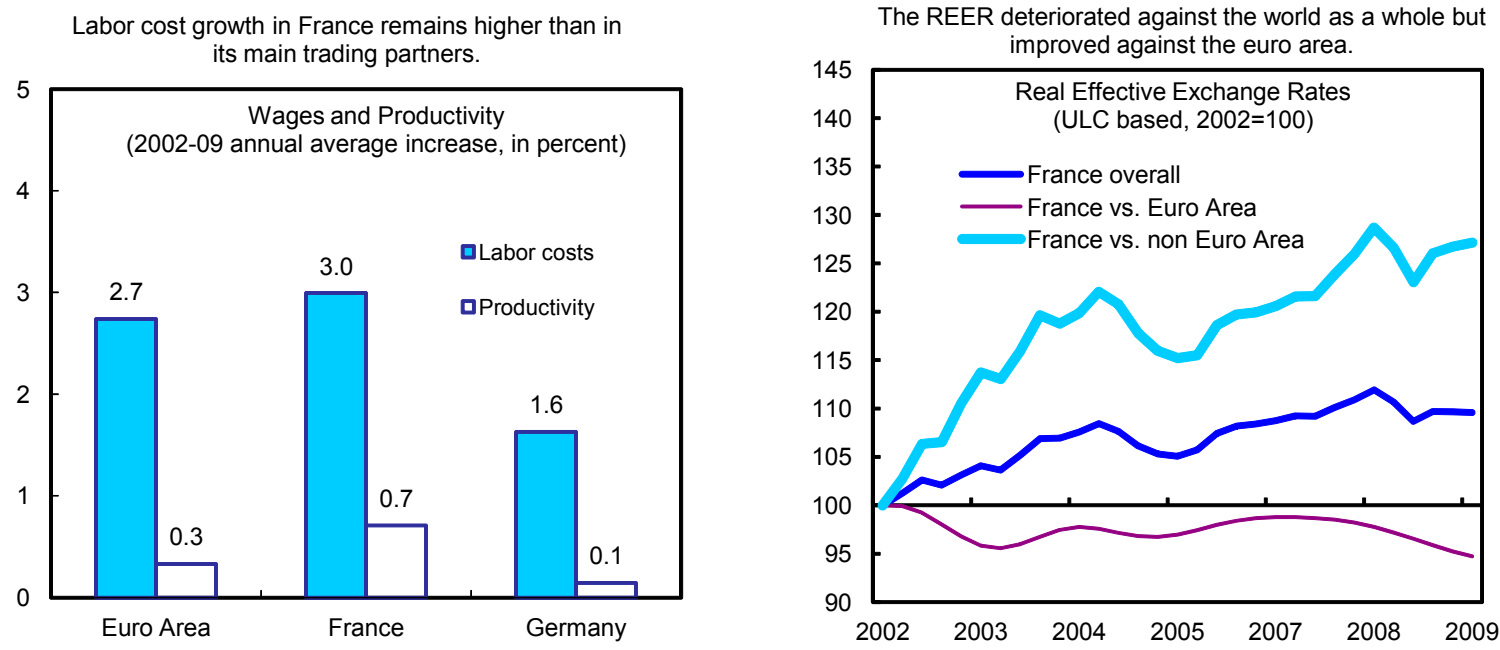

Sources: INSEE; IFS; Eurostat; European Commission; Haver; and IMF staff estimates. 
31. The authorities agreed that with the ongoing sluggish recovery, structural reforms that help increase economic growth in a durable manner are urgent. The recession has done substantial harm to the productive capacity of the French economy and has further increased the already high unemployment rate. In this environment, measures introduced under the Plan de Relance to shield workers and specific sectors, such as the car industry and construction, during the downturn need to be phased out in order to avoid lasting damage to incentives and economic efficiency. At the same time, structural reform efforts must be stepped up to facilitate job creation and achieve higher potential growth. Staff estimates suggest that further labor and product market reforms that would bring France in line with best practices could raise growth by about $3 / 4$ percent per year over the medium term. The mission also emphasized that higher growth in France would help to reduce global imbalances.

32. The main policy priorities in the labor market include facilitating re-absorption of the unemployed and increasing the employment rate. The recent recession caused a substantial increase in the unemployment rate (Box 8). Since the recovery is expected to remain sluggish, unemployment is likely to stay high for some time, calling for policy action to promote job creation. At the same time, the French employment rate remains one of the lowest among OECD countries, especially among seniors, low-skilled, and young workers (Figure 5). The authorities attached great importance to lifting the employment rate to boost potential growth and help restore fiscal sustainability, in part through reducing unemployment-related public expenditures.

\section{The need to re-absorb the unemployed and avoid a rise in structural} unemployment calls for measures to stimulate job creation and to step up activation policies. On the demand side, staff suggested to consider temporary hiring incentives (in the form of credits for new hires or lower payroll contributions) that target vulnerable categories of workers and would encourage employers to take on new employees. On the supply side, the authorities indicated that the unified job placement agency (Pôle emploi) is poised to better support unemployed workers in their job search, while continued efforts to improve training opportunities and reduce skill mismatches would facilitate efficiency-enhancing labor mobility. In addition, staff considered that job-search requirements need to be strictly enforced.

34. Beyond cyclical factors, lifting the low employment rate would require durably improving job-search and hiring incentives and increasing labor force participation, especially among seniors, the youth, and the low-skilled. While progress is being made on this front, the authorities and staff agreed that much remains to be done. The policy priorities in these areas are:

- $\quad$ Eliminating inactivity traps. The high minimum wage (SMIC) keeps potential employees, especially low-skilled and young workers, out of the labor force. Thus, moderation of SMIC increases and the elimination of the coup de pouce should be 
pursued, in order to gradually reestablish a motivating pay scale. Further steps should also be taken to reduce the relatively high tax wedge and employment protection. The recently introduced Working Solidarity Benefit (RSA) is a welcome step toward removing inactivity traps. In addition, the recent creation of the self-employed status should expand the set of job opportunities.

\section{Box 8. Why has Unemployment Increased?}

Notwithstanding the relatively mild recession in France, the unemployment rate has increased on par with many other advanced economies. In particular, the unemployment rate has gone up considerably more in France than in Germany and Italy, both of which have experienced much deeper recessions than France. These developments can be explained by different sensitivities of unemployment to the recent recession in France and its peers.1/

Staff estimates suggest that in normal times the sensitivity of unemployment to real output growth in France is similar to its peers, in particular Germany and Italy. The unemployment dynamics can be explained by Okun's law that relates changes in the unemployment rate to real output growth. Estimates of this model suggest that over the 20 years before the latest recession responses of unemployment to real output growth in France, Germany, and Italy were broadly similar.

However, during the recent recession, the unemployment response in France was stronger than usual, while it was weaker than usual in Germany, Italy, and a few other countries. In France, nearly half of the total unemployment increase during the recession cannot be explained by its depth. Some of this gap can be attributed to the adjustment in specific sectors, including financial services and construction, where the reduction in employment has likely exceeded the decline in the value added. At the same time, generous partial unemployment programs adopted in a number of countries, in particular Germany and Italy, have likely reduced the effect of the recession on unemployment. Staff estimates suggest that in the absence of these programs unemployment would have increased about $1 / 2$ percent more in Germany and $1 \frac{1}{2}$ percent more in Italy.
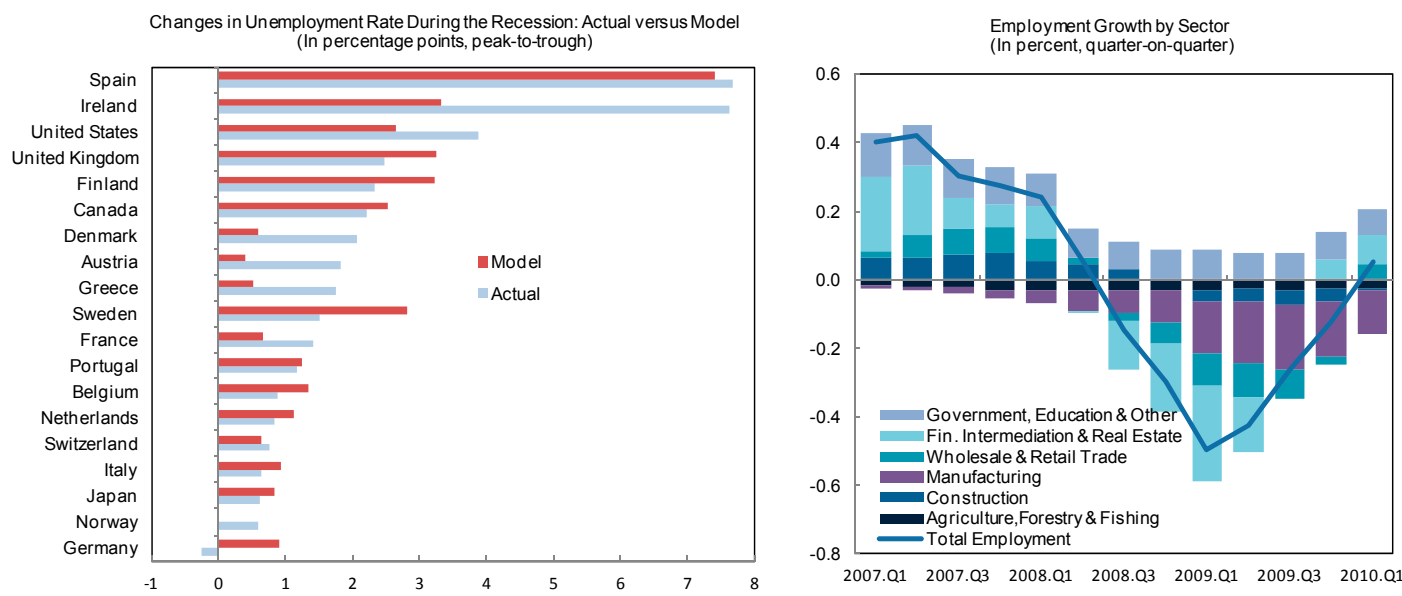

Source: WEO.

1/ International Monetary Fund (2010), Unemployment Dynamics during Recessions and Recoveries: Okun's Law and beyond, World Economic Outlook, April 2010. 
Figure 5. France: Labor Market Indicators
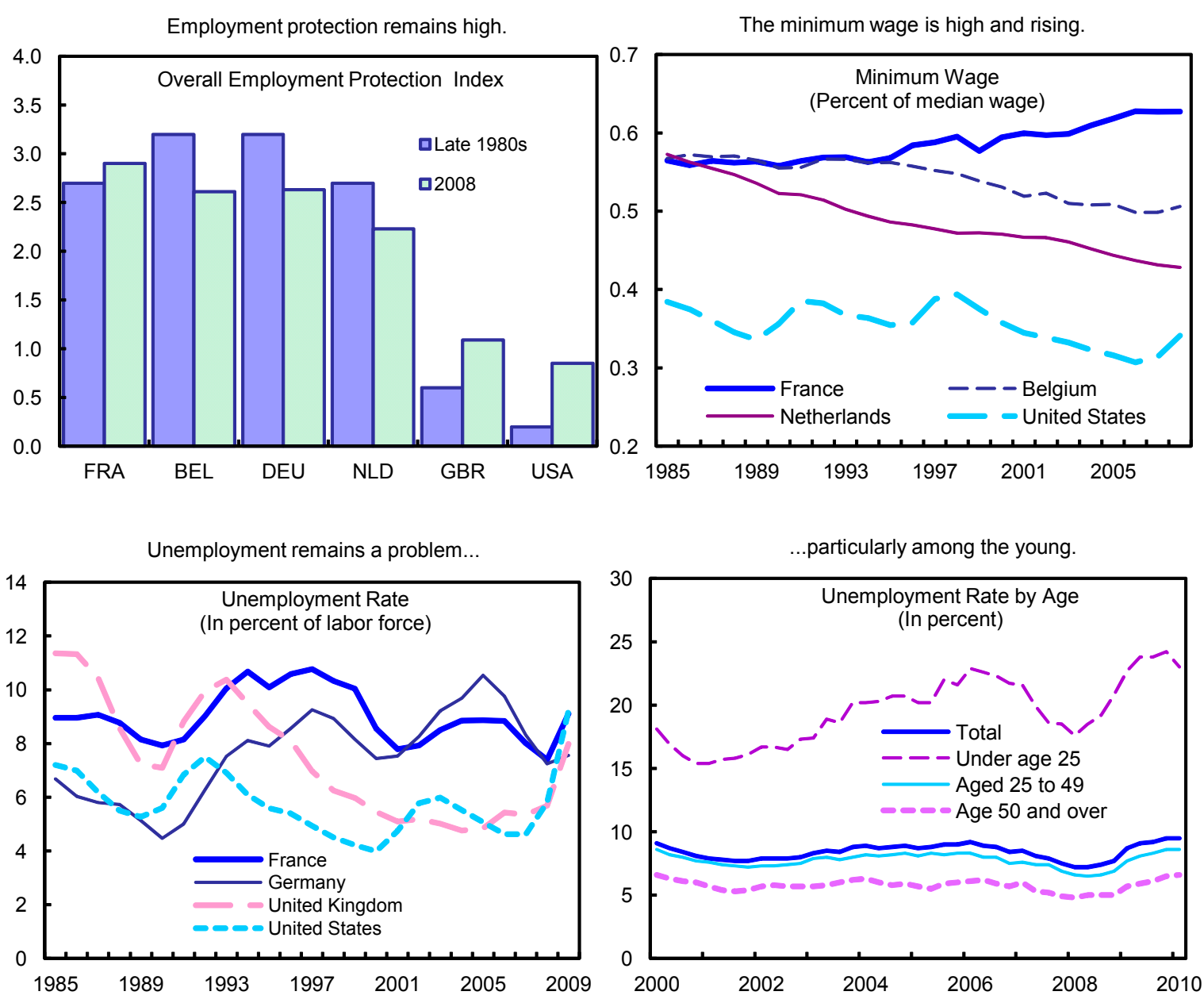

Employment rate is among the lowest.
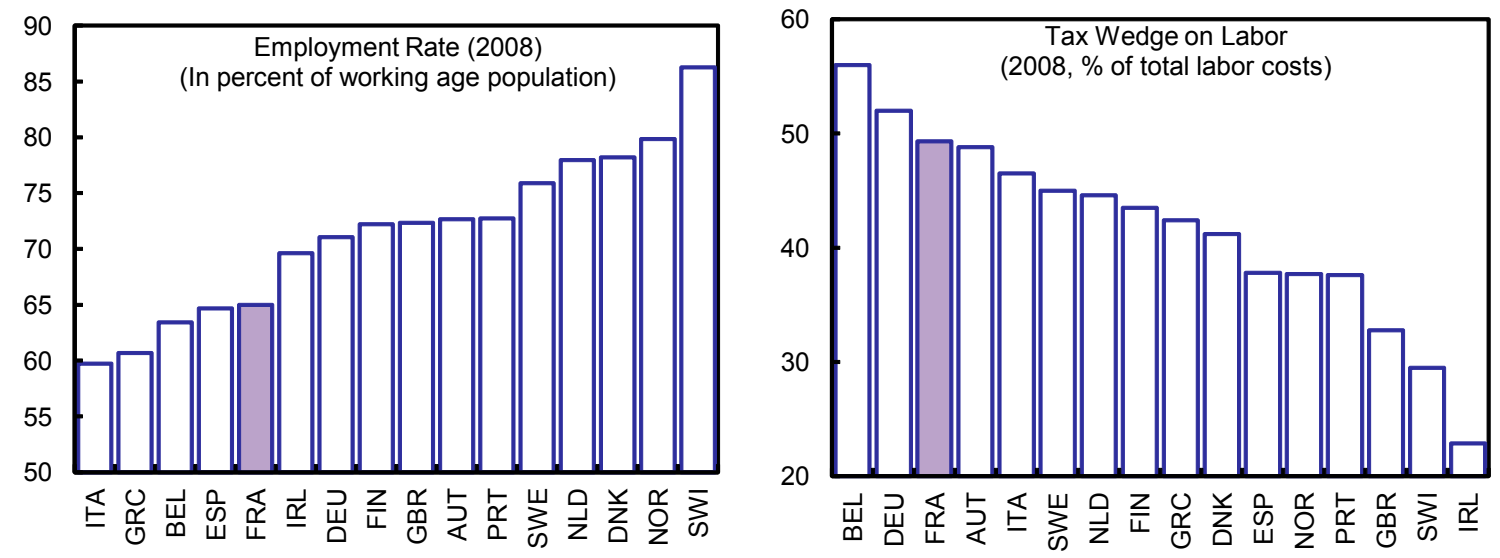

Sources: OECD; Datalnsight; and IMF staff calculations. 
- Integrating senior workers. Weak job-search and hiring incentives contribute to underemployment of senior workers. The removal of financial obstacles to combining earned income with a pension after age 60 and the abolishment of forced retirement before age 70 are steps in the right direction. Increasing the minimum age for pension eligibility, part of the announced pension reform, is a critical step toward raising senior employment and should be combined with improved incentives for continued work, including effective implementation of job-search requirements.

\section{Further enhancing domestic competition would increase economic efficiency.}

While France is gradually catching up with best practices in product market competition reform, the authorities agreed that more needs to be done, particularly in retail trade and services. In retail trade, the Economic Modernization Law (Loi de Modernisation de l'Economie, LME) has introduced measures to strengthen competition and eased some restrictions on new retail establishments, but discounters continue to face administrative limitations to entry into the French market. Deregulating opening hours and sales periods of stores would promote a more competitive environment leading to lower prices for consumers. Also, the benefits to the consumer of ending price regulations on key products, for example over-the-counter drugs, would be enhanced if followed by market liberalization. In the services sector, the EU Services Directive should be followed to achieve further liberalization. Introducing greater competition in health-related services and professional services to businesses and individuals (notaries, accountants) would be welcome.

\section{STAFF APPRAisAL}

36. The French economy weathered the "great recession" better than most of its peers, but the recovery is fragile. The less severe downturn in France can be attributed to the comparatively low trade openness, fairly resilient financial sector, large social safety nets, and timely and decisive government intervention. Nonetheless, the unemployment rate has risen steeply, notably among the young. The financial crisis and economic downturn have exerted a significant toll on public finances, and in the financial sector concerns remain about asset quality, possible spillovers from mature markets, and regulatory uncertainty.

\section{The turbulence in European debt markets and a challenging domestic policy} agenda make the outlook for France highly uncertain. Growth is expected to pick up only slightly during 2010-11. Persistently high unemployment and imminent fiscal consolidation in France and her main trading partners will weigh on demand, while the recent depreciation of the euro will provide some relief. Inflation is expected to remain moderate. Risks to the outlook are mostly on the downside in view of concerns about sovereign risks and possible spillovers in the Euro Area. Potential growth is expected to remain subdued, and the output gap would narrow only gradually. 
38. Under these demanding circumstances, the key policy challenge is to strengthen the foundations of the economy by implementing a credible multiyear fiscal consolidation strategy underpinned by pension reform, supporting the full recovery of the financial system and increasing financial stability, and accelerating progress on structural reforms in order to boost competitiveness, create jobs, and increase economic growth.

\section{The sharply increased public debt and the turbulence in European financial} markets call for significant and credible fiscal consolidation. While the fiscal stimulus in 2009-10 has been appropriate, the authorities must now focus on achieving their objective under the Stability and Growth Pact of reducing the overall fiscal deficit to 3 percent of GDP by 2013. This is crucial to anchor expectations and avoid an unsustainable debt dynamics. The adjustment efforts should concentrate on measures that have the least detrimental impact on economic activity. In particular, entitlement reforms in the pension and health care systems are key while full attention should be given to limiting the growth of local government spending.

\section{The announced fiscal consolidation measures would result in an appropriate} deficit reduction in 2011, but further measures need to be prepared to achieve the medium-term fiscal objectives. Expenditure constraint of the central government, including continued personnel reductions and a nominal freeze of transfers to local governments are important. The recently announced pension reform rightly emphasizes an increase in the effective retirement age in order to reduce the deficit of the pension system over time. Efforts to control local government spending need to be decisively maintained over the medium term. The proposed ban on off-budget introduction of new tax expenditures and exemptions from social security contributions will improve fiscal discipline.

\section{The consolidation effort should be based on realistic macroeconomic} assumptions and supported by a fiscal rule. In order to avoid underestimating the size of the needed fiscal efforts and derailing the consolidation process, the multiyear budget should rely on an independent council to validate the underlying macroeconomic forecasts.

Adopting a fiscal rule would strengthen the consolidation strategy and add credibility both to the national efforts and to the broader European fiscal governance reforms. Staff encourages the authorities to adopt a fiscal rule on the structural general government balance that is enshrined in the highest legislation.

42. French banks are emerging from the crisis with improving profitability but the sluggish recovery and concerns about European sovereign debt pose new risks. Banks have significantly shored up capital adequacy ratios and are gradually exiting from state support. However, nonperforming loans have risen and low growth may put further pressure on loan quality and require additional provisions. Although the direct impact on French banks of the Greek debt problem is likely to be manageable, the counterparty risk and funding risk of French banks vis-à-vis Southern Europe has increased. If needed, the authorities should stand ready to support banks with public refinancing and recapitalization 
schemes. More transparency and better communication of key exposures, in addition to publication of the results of EU-wide stress tests, may help the market's assessment of the French financial system.

\section{Reform of supervisory arrangements has progressed well and France is playing} an active role in promoting international regulatory reforms. The recent unification of banking and insurance supervision is welcome. It is now important to set up the national systemic risk board to enable close cooperation with the envisage European Systemic Risk Board. Staff encourages France to remain engaged in the international regulatory reform process and to actively participate in ongoing macroeconomic impact studies and follow-up work to refine the current reform proposals.

\section{A more competitive and growth-oriented economy is essential for recouping the} output loss incurred during the recession. To catch up with the most competitive countries in the Euro Area and benefit more from the expansion in world trade, wage moderation, promoting competition, and promoting innovation are critical. In view of the considerable growth impact, it is urgent to focus on job creation and improving market efficiency. In addition to labor market activation and training policies, minimum wage moderation should continue to gradually establish a motivating pay scale for young and low-skilled workers. For senior workers, efforts to improve incentives for continued work, including effective jobsearch requirements, need to be pursued. Further deregulation of product markets would enhance economic efficiency and raise welfare. The EU Services Directive should be followed to achieve further liberalization, including in professional services.

45. It is proposed that the next Article IV consultation be held on the regular 12-month cycle. 
Table 1. France: Selected Economic and Social Indicators, 2007-15

\begin{tabular}{|c|c|c|c|c|c|c|c|c|c|}
\hline & \multirow[b]{2}{*}{2007} & \multirow[b]{2}{*}{2008} & \multirow[b]{2}{*}{2009} & \multicolumn{5}{|c|}{ Projections } & \multirow[b]{2}{*}{2015} \\
\hline & & & & 2010 & 2011 & 2012 & 2013 & 2014 & \\
\hline \multicolumn{10}{|l|}{ Real economy (change in percent) } \\
\hline Real GDP & 2.3 & 0.1 & -2.5 & 1.4 & 1.6 & 1.8 & 2.0 & 2.1 & 2.1 \\
\hline Domestic demand & 3.3 & 0.4 & -2.4 & 1.1 & 1.5 & 1.7 & 1.9 & 2.1 & 2.1 \\
\hline $\mathrm{CPI}$ (year average) & 1.6 & 3.2 & 0.1 & 1.3 & 1.6 & 1.8 & 1.9 & 1.9 & 1.9 \\
\hline Unemployment rate (in percent) & 8.4 & 7.8 & 9.5 & 10.0 & 10.1 & 9.7 & 9.2 & 8.7 & 8.4 \\
\hline Gross national savings (percent of GDP) & 21.2 & 19.8 & 16.7 & 17.9 & 18.5 & 18.7 & 18.9 & 19.1 & 19.3 \\
\hline Gross domestic investment (percent of GDP) & 22.2 & 22.0 & 19.0 & 19.5 & 19.9 & 20.1 & 20.2 & 20.4 & 20.6 \\
\hline \multicolumn{10}{|l|}{ Public finance (percent of GDP) } \\
\hline Central government balance & -2.1 & -2.8 & -6.2 & -5.6 & -3.6 & -2.3 & -1.4 & -0.6 & 0.2 \\
\hline General government balance & -2.7 & -3.3 & -7.5 & -8.0 & -6.1 & -4.8 & -3.9 & -3.2 & -2.4 \\
\hline Structural balance (percent of potential GDP) & -3.2 & -3.1 & -5.0 & -4.9 & -3.7 & -3.0 & -2.6 & -2.4 & -2.0 \\
\hline Primary balance & 0.0 & -0.5 & -5.2 & -5.4 & -3.3 & -1.9 & -1.0 & -0.1 & 0.7 \\
\hline General government gross debt $1 /$ & 63.8 & 67.5 & 78.1 & 84.3 & 87.8 & 89.7 & 90.3 & 90.1 & 89.1 \\
\hline \multicolumn{10}{|l|}{ Money and interest rates (in percent) } \\
\hline Money market rate $2 /$ & 4.0 & 3.8 & 1.0 & 0.7 & $\ldots$ & $\ldots$ & $\ldots$ & $\ldots$ & $\ldots$ \\
\hline Government bond yield 2/ & 4.3 & 4.2 & 3.6 & 3.5 & $\ldots$ & $\ldots$ & $\ldots$ & $\ldots$ & $\ldots$ \\
\hline \multicolumn{10}{|l|}{ Balance of payments (in percent of GDP) } \\
\hline Exports of goods & 21.1 & 21.1 & 17.8 & 20.7 & 20.8 & 20.9 & 21.0 & 21.1 & 21.1 \\
\hline Volume growth (in percent) & 2.5 & -0.8 & -12.2 & 6.8 & 3.3 & 3.5 & 3.6 & 3.7 & 3.8 \\
\hline Imports of goods & 23.2 & 24.1 & 20.2 & 22.7 & 22.7 & 22.6 & 22.6 & 22.7 & 22.8 \\
\hline Volume growth (in percent) & 5.7 & 0.3 & -10.6 & 5.1 & 2.6 & 2.9 & 3.3 & 3.6 & 3.8 \\
\hline Trade balance & -2.1 & -3.0 & -2.5 & -1.9 & -1.8 & -1.7 & -1.7 & -1.6 & -1.6 \\
\hline Current account & -1.0 & -2.3 & -2.2 & -1.6 & -1.5 & -1.4 & -1.4 & -1.3 & -1.3 \\
\hline FDI (net) & -2.5 & -3.6 & -3.8 & -2.3 & -2.2 & -2.1 & -2.0 & -1.9 & -1.8 \\
\hline Official reserves (US\$ billion) & 45.7 & 33.6 & 46.6 & $\ldots$ & $\ldots$ & $\ldots$ & $\ldots$ & $\ldots$ & $\ldots$ \\
\hline \multicolumn{10}{|l|}{ Fund position (as of May 31, 2010) } \\
\hline Holdings of currency (percent of quota) & & & 76.2 & & & & & & \\
\hline Holdings of SDRs (percent of allocation) & & & 95.9 & & & & & & \\
\hline Quota (SDRs million) & & & 10,739 & & & & & & \\
\hline \multicolumn{10}{|l|}{ Exchange rates } \\
\hline Euro per U.S. dollar 2/ & 0.73 & 0.68 & 0.72 & 0.76 & $\ldots$ & $\ldots$ & $\ldots$ & $\ldots$ & $\ldots$ \\
\hline Nominal effective rate $(2000=100)$ & 102.4 & 104.9 & 104.3 & $\ldots$ & $\ldots$ & $\ldots$ & $\ldots$ & $\ldots$ & $\ldots$ \\
\hline Real effective exchange rate $(2000=100)$ & 103.2 & 105.3 & 101.0 & $\ldots$ & $\ldots$ & $\ldots$ & $\ldots$ & $\ldots$ & $\ldots$ \\
\hline \multicolumn{10}{|l|}{ Potential output and output gap } \\
\hline Potential output & 2.1 & 1.6 & 1.1 & 1.1 & 1.1 & 1.2 & 1.2 & 1.3 & 1.4 \\
\hline Output gap & 1.1 & -0.4 & -3.9 & -3.6 & -3.0 & -2.4 & -1.7 & -0.9 & -0.2 \\
\hline \multicolumn{10}{|l|}{ Social indicators } \\
\hline \multicolumn{10}{|c|}{ Per capita GDP (2006): US $\$ 35,471$; Life expectancy at birth (2006): 77.2 (male) and 84.1 (female); } \\
\hline \multicolumn{10}{|c|}{ Poverty rate (2005): 12.1 percent (60 percent line), 6.3 percent (50 percent line); } \\
\hline \multicolumn{10}{|c|}{ Income distribution (ratio of income received by top and bottom quintiles, 2004): 4.2. } \\
\hline
\end{tabular}


Table 2. France: Balance of Payments, 2007-15

(Percent of GDP)

\begin{tabular}{|c|c|c|c|c|c|c|c|c|c|}
\hline & \multirow[b]{2}{*}{2007} & \multirow[b]{2}{*}{2008} & \multicolumn{7}{|c|}{ Projections } \\
\hline & & & 2009 & 2010 & 2011 & 2012 & 2013 & 2014 & 2015 \\
\hline Balance on current account & -1.0 & -2.3 & -2.2 & -1.6 & -1.5 & -1.4 & -1.4 & -1.3 & -1.3 \\
\hline Balance on goods and services & -1.3 & -2.3 & -1.9 & -1.4 & -1.3 & -1.2 & -1.2 & -1.2 & -1.2 \\
\hline Balance of trade (f.o.b., c.i.f.) & -2.1 & -3.0 & -2.5 & -1.9 & -1.8 & -1.7 & -1.7 & -1.6 & -1.6 \\
\hline Exports of goods and services & 26.8 & 26.8 & 23.0 & 26.2 & 26.2 & 26.1 & 26.0 & 26.0 & 25.9 \\
\hline Exports of goods & 21.1 & 21.1 & 17.8 & 20.7 & 20.8 & 20.9 & 21.0 & 21.1 & 21.1 \\
\hline Exports of services & 5.8 & 5.7 & 5.3 & 5.5 & 5.3 & 5.2 & 5.0 & 4.9 & 4.7 \\
\hline Imports of goods and services & -28.2 & -29.1 & -25.0 & -27.6 & -27.5 & -27.3 & -27.2 & -27.1 & -27.1 \\
\hline Imports of goods (f.o.b.) & -23.2 & -24.1 & -20.2 & -22.7 & -22.7 & -22.6 & -22.6 & -22.7 & -22.8 \\
\hline Imports of services & -5.0 & -5.0 & -4.8 & -4.9 & -4.8 & -4.7 & -4.5 & -4.4 & -4.3 \\
\hline Income, net & 1.5 & 1.3 & 1.0 & 1.1 & 1.2 & 1.2 & 1.2 & 1.2 & 1.2 \\
\hline Current transfers, net & -1.2 & -1.2 & -1.3 & -1.3 & -1.3 & -1.3 & -1.3 & -1.3 & -1.4 \\
\hline Balance on capital account & 0.1 & 0.0 & 0.1 & -0.1 & 0.0 & 0.0 & 0.0 & 0.0 & 0.0 \\
\hline Balance on financial account & 2.0 & 4.0 & 1.3 & 1.7 & 1.5 & 1.4 & 1.4 & 1.3 & 1.3 \\
\hline Direct investment, net & -2.5 & -3.6 & -3.8 & -2.3 & -2.2 & -2.1 & -2.0 & -1.9 & -1.8 \\
\hline Portfolio investment, net & -6.4 & 4.6 & 12.5 & 2.7 & 2.5 & 2.5 & 2.4 & 2.3 & 2.2 \\
\hline Other investment, net & 8.5 & 3.0 & -7.4 & 1.1 & 1.1 & 1.0 & 1.0 & 0.9 & 0.9 \\
\hline Reserve assets & 0.0 & 0.4 & 0.2 & 0.1 & 0.1 & 0.0 & 0.0 & 0.0 & 0.0 \\
\hline Errors and omissions, net & -1.1 & -1.8 & 0.8 & 0.0 & 0.0 & 0.0 & 0.0 & 0.0 & 0.0 \\
\hline
\end{tabular}

Sources: French authorities; IMF staff estimates and projections. 
Table 3. France: General Government Accounts, 2007-15

(In percent of GDP, unless otherwise indicated)

\begin{tabular}{|c|c|c|c|c|c|c|c|c|c|}
\hline & \multirow[b]{2}{*}{2007} & \multirow[b]{2}{*}{2008} & \multirow[b]{2}{*}{2009} & \multicolumn{5}{|c|}{ Projections } & \multirow[b]{2}{*}{2015} \\
\hline & & & & 2010 & 2011 & 2012 & 2013 & 2014 & \\
\hline \multicolumn{10}{|l|}{ General government } \\
\hline Revenue & 49.6 & 49.5 & 48.4 & 48.3 & 49.5 & 50.0 & 50.1 & 50.1 & 50.1 \\
\hline Tax revenue & 42.9 & 42.6 & 41.4 & 41.4 & 42.6 & 43.1 & 43.2 & 43.2 & 43.2 \\
\hline \multicolumn{10}{|l|}{ Of which } \\
\hline VAT & 7.2 & 7.0 & $\ldots$ & $\ldots$ & $\ldots$ & $\ldots$ & $\ldots$ & $\ldots$ & $\ldots$ \\
\hline Income tax & 2.6 & 2.6 & $\ldots$ & $\ldots$ & $\ldots$ & $\ldots$ & $\ldots$ & $\ldots$ & $\ldots$ \\
\hline Corporate tax & 2.7 & 2.5 & $\ldots$ & $\ldots$ & $\ldots$ & $\ldots$ & $\ldots$ & $\ldots$ & $\ldots$ \\
\hline TIPP & 1.3 & 1.2 & $\ldots$ & $\ldots$ & $\ldots$ & $\ldots$ & $\ldots$ & $\ldots$ & $\ldots$ \\
\hline Nontax revenue & 6.7 & 6.8 & 7.0 & 6.9 & 6.9 & 6.9 & 6.9 & 6.9 & 6.9 \\
\hline Expenditures & 52.3 & 52.8 & 56.0 & 56.3 & 55.6 & 54.9 & 54.1 & 53.3 & 52.5 \\
\hline Primary exp. & 49.6 & 49.9 & 53.6 & 53.7 & 52.8 & 52.0 & 51.1 & 50.2 & 49.4 \\
\hline \multicolumn{10}{|l|}{ Of which } \\
\hline Salaries & 12.8 & 12.7 & 13.2 & $\ldots$ & $\ldots$ & $\ldots$ & $\ldots$ & $\ldots$ & $\ldots$ \\
\hline Pensions and Healthcare & 23.1 & 23.3 & 24.9 & $\ldots$ & $\ldots$ & $\ldots$ & $\ldots$ & $\ldots$ & $\ldots$ \\
\hline Other social transfers & 4.9 & 5.1 & 5.7 & $\ldots$ & $\ldots$ & $\ldots$ & $\ldots$ & $\ldots$ & $\ldots$ \\
\hline Debt service & 2.7 & 2.9 & 2.4 & 2.6 & 2.8 & 2.9 & 3.0 & 3.1 & 3.1 \\
\hline Balance 1/ & -2.7 & -3.3 & -7.5 & -8.0 & -6.1 & -4.8 & -3.9 & -3.2 & -2.4 \\
\hline Primary balance & 0.0 & -0.5 & -5.2 & -5.4 & -3.3 & -1.9 & -1.0 & -0.1 & 0.7 \\
\hline Structural balance $2 /$ & -3.2 & -3.1 & -5.0 & -4.9 & -3.7 & -3.0 & -2.6 & -2.4 & -2.0 \\
\hline Central government balance $1 /$ & -2.1 & -2.8 & -6.2 & -5.6 & -3.6 & -2.3 & -1.4 & -0.6 & 0.2 \\
\hline Social security balance $1 /$ & 0.0 & 0.0 & -1.3 & $\ldots$ & $\ldots$ & $\ldots$ & $\ldots$ & $\ldots$ & $\ldots$ \\
\hline Local government balance 1/ & -0.4 & -0.4 & -0.3 & $\ldots$ & $\cdots$ & $\ldots$ & $\ldots$ & $\ldots$ & $\ldots$ \\
\hline ODAC balance $1 /$ & -0.2 & 0.0 & 0.1 & $\ldots$ & $\ldots$ & $\ldots$ & $\ldots$ & $\ldots$ & $\ldots$ \\
\hline Gross debt $3 /$ & 63.8 & 67.5 & 78.1 & 84.3 & 87.8 & 89.7 & 90.3 & 90.1 & 89.1 \\
\hline Interest payments & 2.7 & 2.9 & 2.4 & 2.6 & 2.8 & 2.9 & 3.0 & 3.1 & 3.1 \\
\hline \multicolumn{10}{|l|}{ Memorandum items: } \\
\hline Nominal GDP (in billion of Euros) & 1,895 & 1,949 & 1,907 & 1,951 & 2,013 & 2,084 & 2,163 & 2,249 & 2,338 \\
\hline Structural nominal GDP (in billion of Euros) & 1,876 & 1,954 & 1,986 & 2,024 & 2,076 & 2,136 & 2,201 & 2,270 & 2,344 \\
\hline Real GDP growth (in percent) & 2.3 & 0.1 & -2.5 & 1.4 & 1.6 & 1.8 & 2.0 & 2.1 & 2.1 \\
\hline Real expenditure growth (in percent) & 2.5 & 0.6 & 3.7 & 1.6 & 0.3 & 0.4 & 0.3 & 0.7 & 0.5 \\
\hline of which: primary & 2.3 & 0.3 & 5.0 & 1.2 & -0.2 & 0.1 & 0.1 & 0.4 & 0.4 \\
\hline of which: structural primary $4 /$ & 2.6 & 0.5 & 4.2 & 0.5 & 0.3 & 0.3 & 0.3 & 0.5 & 0.5 \\
\hline
\end{tabular}

Sources: French authorities; IMF staff estimates and projections.

1/ Maastricht definition.

2/ In percent of potential GDP.

3/ The debt figure, based on Maastricht definition, does not include guarantees on nongeneral government debt.

4/ Excludes fiscal stimulus package and unemployment benefits. 
Table 4. France: High-Frequency Financial Indicators

\begin{tabular}{|c|c|c|c|c|c|c|}
\hline & \multicolumn{6}{|c|}{ Change since: } \\
\hline & April 27, 2010 & 30 days & Jan.1, 2009 & Sep.1, 2008 & Jan.1, 2008 & Jan.1, 2007 \\
\hline \multicolumn{7}{|c|}{ Financial institution equity prices $1 /$} \\
\hline BNP Paribas & 50.7 & -13.6 & 72.6 & -15.6 & -29.7 & -36.8 \\
\hline Credit Agricole & 11.4 & -12.1 & 43.0 & -20.0 & -46.3 & -60.4 \\
\hline Societe Generale & 41.0 & -12.9 & 20.3 & -34.4 & -53.2 & -64.0 \\
\hline \multicolumn{7}{|l|}{ Credit default swap spreads $2 /$} \\
\hline BNP Paribas & 95.9 & 25.9 & 24.6 & 32.4 & 68.2 & 90.0 \\
\hline Credit Agricole & 131.4 & 44.5 & 48.5 & 36.6 & 90.4 & 125.1 \\
\hline Societe Generale & 118.1 & 33.8 & 8.7 & 28.9 & 88.4 & 112.0 \\
\hline \multicolumn{7}{|l|}{ Stock indices $3 /$} \\
\hline CAC 40 & 3844.6 & -3.6 & 19.5 & -14.0 & -31.5 & -30.6 \\
\hline Euro stoxx 50 & 2838.8 & -3.5 & 16.0 & -15.6 & -35.5 & -31.1 \\
\hline \multicolumn{7}{|l|}{ Interbank interest rates 4/ } \\
\hline Overnight & 0.3 & 3.6 & -85.3 & -91.9 & -91.2 & -90.6 \\
\hline 3-month & 0.6 & 1.6 & -77.7 & -87.0 & -86.2 & -82.7 \\
\hline \multicolumn{7}{|l|}{ Government interest rates 4/ } \\
\hline 3-month & 0.2 & -4.9 & -85.3 & -94.4 & -93.6 & -92.9 \\
\hline 10-year & 3.3 & -6.0 & -4.4 & -24.6 & -26.1 & -18.0 \\
\hline Money market risk spread 5/ & 40.2 & 38.0 & 123.5 & 64.1 & 89.4 & 29.2 \\
\hline
\end{tabular}

Sources: Bloomberg; Datastream.

1/Euros; change in percentage points.

2/ Basis points, 5-year CDS.

$3 /$ Index; change in percentage points.

4/ Percent; change in percentage points.

5/ Basis points; 3-month interbank rate minus 3-month Treasury Bill. 
Table 5. France: Vulnerability Indicators, 2003-10

(In percent of GDP; unless otherwise indicated)

\begin{tabular}{|c|c|c|c|c|c|c|c|c|c|}
\hline & & & & & & & & Estimate & Date \\
\hline & 2003 & 2004 & 2005 & 2006 & 2007 & 2008 & $2009^{-}$ & 2010 & \\
\hline \multicolumn{10}{|l|}{ External Indicators } \\
\hline Exports (annual percentage change, in U.S. dollars) & 19.7 & 18.7 & 9.0 & 12.1 & 6.5 & 0.9 & -5.6 & $\ldots$ & Q1 \\
\hline Imports (annual percentage change, in U.S. dollars) & 21.6 & 19.6 & 12.4 & 12.3 & 7.8 & 4.3 & -5.1 & $\ldots$ & Q1 \\
\hline Terms of trade (annual percentage change) & -0.2 & -0.7 & -1.0 & -0.7 & 0.8 & 0.0 & 1.8 & $\ldots$ & $\ldots$ \\
\hline Current account balance & 0.8 & 0.6 & -0.4 & -0.5 & -1.0 & -2.3 & -3.0 & $\ldots$ & Q1 \\
\hline Capital and financial account balance & & -0.4 & -1.1 & -0.8 & 1.3 & 2.9 & 3.0 & $\ldots$ & $\ldots$ \\
\hline \multicolumn{10}{|l|}{ Of which } \\
\hline Inward portfolio investment (debt securities, etc.) & 11.1 & 8.0 & 10.5 & 10.1 & 1.5 & 6.2 & 6.3 & $\ldots$ & $\ldots$ \\
\hline Inward foreign direct investment & 2.4 & 1.5 & 3.0 & 2.8 & 6.1 & 4.4 & 4.5 & $\ldots$ & $\ldots$ \\
\hline Other investment (net) & 1.4 & 3.8 & 1.2 & 1.1 & 10.7 & 2.8 & 2.9 & $\ldots$ & $\ldots$ \\
\hline \multicolumn{10}{|l|}{ Total reserves minus gold } \\
\hline (in billions of U.S. dollars, end-of-period) & 30.2 & 35.3 & 27.8 & 42.7 & 45.7 & 33.6 & 46.6 & 48.1 & March \\
\hline Euros per U.S. dollar (period average) & 0.8 & 0.7 & 0.8 & 0.8 & 0.8 & 0.8 & 0.7 & 0.7 & March \\
\hline \multicolumn{10}{|l|}{ Market Indicators } \\
\hline \multicolumn{10}{|l|}{ Financial Markets } \\
\hline Public sector debt $1 /$ & 62.9 & 64.9 & 66.4 & 63.7 & 63.8 & 67.4 & 71.2 & $\ldots$ & Q1 \\
\hline 3-month T-bill yield (percentage points, eop) & 2.1 & 2.0 & 2.3 & 3.5 & 3.8 & 1.9 & 0.4 & 0.3 & March \\
\hline 3-month T-bill yield in real terms (percentage points, eop) & -0.3 & -0.3 & 0.6 & 1.8 & 1.0 & 0.7 & -0.7 & $\ldots$ & \\
\hline US 3 month T-bill & 0.9 & 2.2 & 3.9 & 4.8 & 3.1 & 0.0 & 0.1 & 0.2 & March \\
\hline Spread with the US T-bill (percentage points, eop) & 1.2 & -0.2 & -1.6 & -1.4 & 0.7 & 1.9 & 0.3 & 0.2 & March \\
\hline 5 - to 8-year government bond (percentage points, eop) & 4.3 & 3.6 & 3.4 & 3.8 & 4.4 & 3.5 & 3.5 & 3.4 & March \\
\hline 10-year government bond (United States) & 4.3 & 4.2 & 4.5 & 4.6 & 4.1 & 2.4 & 3.6 & 3.7 & March \\
\hline Spread with US bond (percentage points, eop) & 0.1 & -0.6 & -1.1 & -0.8 & 0.3 & 1.1 & -0.1 & -0.3 & March \\
\hline Yield curve (10 year - 3 month, percentage points, eop) & 2.3 & 1.6 & 1.1 & 0.3 & 0.5 & 1.6 & 3.1 & 3.1 & March \\
\hline Stock market index (period average) & 166.5 & 196.9 & 228.0 & 273.1 & 306.1 & 232.0 & 205.8 & 209.6 & March \\
\hline Real estate prices (index, $2000=100$, period average) & 135.6 & 156.5 & 172.9 & 185.1 & 192.1 & 187.3 & 182.2 & & Q1 \\
\hline \multicolumn{10}{|l|}{ Credit markets (end-of-period 12-month growth rates) } \\
\hline Credit to the private sector & 5.2 & 8.3 & 8.9 & 6.9 & 13.5 & 5.9 & 1.8 & $\ldots$ & Apr \\
\hline Bank credit to households & 7.8 & 9.6 & 11.7 & 11.0 & 11.0 & 6.9 & 5.6 & $\ldots$ & Apr \\
\hline Housing Loans & 9.9 & 13.6 & 15.0 & 15.0 & 12.8 & 5.9 & 7.6 & $\begin{array}{l}\cdots \\
\cdots\end{array}$ & Apr \\
\hline Bank credit to nonfinancial enterprises & -1.1 & 6.0 & 7.2 & 6.0 & 13.7 & 9.4 & 5.9 & $\ldots$ & Apr \\
\hline \multicolumn{10}{|l|}{ Sectoral risk indicators } \\
\hline \multicolumn{10}{|l|}{ Household sector } \\
\hline Household savings ratio & 15.8 & 15.8 & 14.9 & 15.1 & 15.5 & 15.4 & 16.2 & $\ldots$ & $\ldots$ \\
\hline Household financial savings ratio & 6.6 & 6.2 & 5.0 & 4.7 & 4.8 & 4.8 & 6.8 & $\cdots$ & $\cdots$ \\
\hline Real estate household solvency ratio (index, 2000=100) $2 /$ & 96 & 90 & 91 & 92 & 94 & 95 & $\ldots$ & $\cdots$ & $\cdots$ \\
\hline Corporate sector & & & & & & & & $\cdots$ & \\
\hline Profitability of business sector (financial margin) & 37.9 & 37.6 & 37.4 & 37.7 & 38.5 & 38.1 & 36.4 & $\begin{array}{l}\cdots \\
\cdots\end{array}$ & $\ldots$ \\
\hline Investment ratio & 17.0 & 17.3 & 17.8 & 18.3 & 19.2 & 19.6 & 18.7 & $\ldots$ & $\ldots$ \\
\hline Savings ratio & 15.9 & 14.7 & 13.8 & 13.8 & 15.5 & 13.6 & 12.8 & $\cdots$ & $\cdots$ \\
\hline Self-financing ratio & 87.4 & 79.1 & 72.2 & 70.2 & 75.3 & 64.4 & 63.6 & $\cdots$ & $\cdots$ \\
\hline Banking sector & & & & & & & & $\ldots$ & \\
\hline Share of housing loans in bank credit to the private sector & 32.8 & 34.7 & 36.6 & 36.4 & 36.6 & 34.9 & 38.8 & $\ldots$ & Apr \\
\hline Share of nonperforming loans in total loans & 4.8 & 4.2 & 3.5 & 3.0 & 2.7 & 2.8 & 3.6 & $\cdots$ & $\ldots$ \\
\hline Ratio of nonperforming loans net of provisions to capital & 11.6 & 9.8 & 8.6 & 6.8 & 6.6 & 8.2 & 10.8 & $\ldots$ & $\ldots$ \\
\hline Liquid assets to total short-term liabilities & 153.7 & 155.1 & 150.1 & 146.7 & 150.3 & 139.6 & 150.1 & $\ldots$ & $\ldots$ \\
\hline Return on assets & 0.4 & 0.5 & 0.6 & 0.6 & 0.4 & 0.0 & 0.4 & $\ldots$ & $\ldots$ \\
\hline Return on equity & 8.5 & 10.6 & 11.8 & 14.0 & 9.8 & -1.0 & 8.2 & $\ldots$ & $\ldots$ \\
\hline Regulatory capital to risk-weighted assets & 11.9 & 11.5 & 11.3 & 10.9 & 10.2 & 10.5 & 12.4 & $\ldots$ & $\ldots$ \\
\hline
\end{tabular}

Sources: French authorities; FNAIM; IMF, International Financial Statistics; and Bloomberg.

$1 /$ The debt figure does not include guarantees on non-general government debt.

2/ This index combines the effect of real disposable income, repayment conditions for loans, real estate prices, and interest subsidies. 
Table 6. France: The Core Set of Financial Soundness Indicators, 2002-09

\begin{tabular}{|c|c|c|c|c|c|c|c|}
\hline Indicator & 2003 & 2004 & 2005 & 2006 & 2007 & 2008 & $\frac{\text { Estimate }}{2009}$ \\
\hline \multicolumn{8}{|l|}{ Deposit-taking institutions 1/ } \\
\hline Regulatory capital to risk-weighted assets & 11.9 & 11.5 & 11.3 & 10.9 & 10.2 & 10.5 & 12.4 \\
\hline Regulatory Tier I capital to risk-weighted assets & 9.0 & 8.8 & 8.2 & 8.2 & 7.7 & 8.5 & 10.2 \\
\hline Nonperforming loans net of provisions to capital & 11.6 & 9.8 & 8.6 & 6.8 & 6.6 & 8.2 & 10.8 \\
\hline Bank provisions to Nonperforming loans & n.a. & n.a. & n.a. & 170 & 158.3 & 131.0 & 109.4 \\
\hline Nonperforming loans to total gross loans & 4.8 & 4.2 & 3.5 & 3.0 & 2.7 & 2.8 & 3.6 \\
\hline \multicolumn{8}{|l|}{ Sectoral distribution of loans to total loans, of which } \\
\hline Deposit-takers & 34.2 & 34.0 & 30.1 & 30.6 & 32.2 & 33.6 & 34.1 \\
\hline Nonfinancial corporation & 18.9 & 18.7 & 18.8 & 18.6 & 18.1 & 18.3 & 17.5 \\
\hline Households (including individual firms) & 24.5 & 24.9 & 26.5 & 26.6 & 24.8 & 24.1 & 24.5 \\
\hline Nonresidents (including financial sectors) & 4.3 & 4.2 & 4.7 & 4.2 & 4.7 & 4.7 & 4.6 \\
\hline ROA (aggregated data on a parent-company basis) 2/ & 0.44 & 0.5 & 0.6 & 0.6 & 0.4 & 0.0 & 0.4 \\
\hline ROA (main groups on a consolidated basis) $3 /$ & 0.39 & 0.53 & 0.49 & 0.57 & 0.35 & 0.1 & 0.3 \\
\hline ROE (aggregated data on a parent-company basis) 2/ & 8.50 & 10.6 & 11.8 & 14.0 & 9.8 & -1.0 & 8.2 \\
\hline ROE (main groups on a consolidated basis) $3 /$ & 10.0 & 12.7 & 13.5 & 17.22 & 13.34 & 3.8 & 6.4 \\
\hline Interest margin to gross income & 35.5 & 33.2 & 32.4 & 28.2 & 25.3 & 40.4 & 34.9 \\
\hline Noninterest expenses to gross income & 64.4 & 63.9 & 64.3 & 62.4 & 68.4 & 84.2 & 63.1 \\
\hline Liquid assets to total assets & 21.6 & 21.3 & 20.5 & 19.9 & 18.9 & 18.3 & 18.3 \\
\hline Liquid assets to short-term liabilities & 153.7 & 155.1 & 150.1 & 146.7 & 150.3 & 139.6 & 150.1 \\
\hline \multicolumn{8}{|l|}{ Net open position in foreign exchange to capital } \\
\hline Net open positions in FX (in millions of euros) 4/ & 4,772 & 6,669 & 5275 & 5,283 & 7,058 & n.a. & n.a. \\
\hline Net open positions in equities to Tier I capital & 3.5 & 4.8 & n.a. & n.a. & n.a. & n.a. & n.a. \\
\hline
\end{tabular}

Sources: Banque de France, ACP

1/ These may be grouped in different peer groups based on control, business lines, or group structure.

2/ All credit institutions' aggregated data on a parent-company basis.

3 / Consolidated data for the seven main banking groups (2005, IFRS).

$4 /$ Impact of the creation of the euro has to be taken into account. 
Table 7. France: Encouraged Financial Soundness Indicators, 2002-09

(In percent, unless otherwise indicated)

\begin{tabular}{|c|c|c|c|c|c|c|c|c|}
\hline \multirow[b]{2}{*}{ Indicator } & \multirow[b]{2}{*}{2002} & \multirow[b]{2}{*}{2003} & \multirow[b]{2}{*}{2004} & \multirow[b]{2}{*}{2005} & \multirow[b]{2}{*}{2006} & \multirow[b]{2}{*}{2007} & \multicolumn{2}{|c|}{ Estimate } \\
\hline & & & & & & & 2008 & 2009 \\
\hline \multicolumn{9}{|l|}{ Corporate sector } \\
\hline Total debt to equity & 84.1 & 72.6 & 68.7 & 65.4 & 57.2 & 54.7 & 87.0 & 74.0 \\
\hline Return on equity & 11.1 & 9.4 & 9.2 & 9.1 & 9.6 & 9.5 & 8.8 & 7.3 \\
\hline Interest paid to financial firms $1 /$ & 29.4 & 27.2 & 25.4 & 25.9 & 28.8 & 33.9 & 32.9 & 19.8 \\
\hline Corporate net foreign exchange exposure to equity & n.a. & n.a. & n.a. & n.a. & n.a. & n.a. & n.a. & n.a. \\
\hline Number of enterprise bankruptcies (thousands) & 44.9 & 47.2 & 48.4 & 49.3 & 47.9 & 51.3 & 55.6 & 63.3 \\
\hline Number of enterprise creations (thousands) & 214.9 & 239.0 & 269.0 & 271.2 & 285.5 & 325.7 & 331.4 & 580.2 \\
\hline \multicolumn{9}{|l|}{ Deposit-taking institutions } \\
\hline Capital (net worth) to assets & 5.2 & 5.4 & 5.1 & 4.4 & 4.5 & 4.1 & 4.2 & 4.5 \\
\hline \multicolumn{9}{|l|}{$\begin{array}{l}\text { International consolidated claims of French banks, of which } \\
\text { (BIS data, as percent of total international claims) }\end{array}$} \\
\hline Advanced countries & 84.0 & 85.3 & 84.2 & 83.7 & 85.1 & 84.0 & 84.2 & 83.3 \\
\hline Developing Europe & 2.2 & 2.7 & 2.6 & 2.8 & 3.2 & 4.0 & 4.3 & 4.6 \\
\hline Latin America and Caribbean & 1.8 & 1.4 & 1.0 & 1.1 & 0.9 & 1.0 & 1.1 & 1.2 \\
\hline Africa and Middle East & 3.6 & 3.3 & 3.1 & 3.1 & 2.6 & 2.6 & 3.1 & 3.5 \\
\hline Asia and Pacific Area & 2.8 & 2.7 & 2.6 & 2.6 & 2.5 & 2.9 & 2.6 & 2.9 \\
\hline Offshore Financial Centers & 5.6 & 4.5 & 6.5 & 6.6 & 5.6 & 5.5 & 4.7 & 4.4 \\
\hline Gross asset position in financial derivatives to capital & 378.9 & 306.8 & 372.5 & 543.7 & 337.0 & 235.0 & n.a. & n.a. \\
\hline Gross liability position in financial derivatives to capital & 343.5 & 282.7 & 358.5 & 484.7 & 293.0 & 227.0 & n.a. & n.a. \\
\hline Large exposures to capital & 5.2 & 0.9 & 4.6 & 3.6 & 1.4 & 4.7 & 3.1 & 4.1 \\
\hline Trading income to total income & 2.4 & 16.8 & 20.0 & 23.9 & 26.0 & 16.8 & -63.9 & 16.4 \\
\hline Personnel expenses to noninterest expenses & 55.2 & 56.0 & 56.5 & 58.3 & 54.0 & 53.3 & 51.6 & 61.1 \\
\hline Spread between reference lending and deposit rates & n.a. & n.a. & n.a. & n.a. & n.a. & n.a. & n.a. & n.a. \\
\hline Spread between highest and lowest interbank rate & n.a. & n.a. & n.a. & n.a. & n.a. & n.a. & n.a. & n.a. \\
\hline Customer deposits to total (noninterbank) loans & 81.5 & 82.8 & 80.6 & 83.5 & 80.5 & 77.4 & 78.0 & 85.3 \\
\hline FX loans to total loans $2 /$ & 12.6 & 11.2 & 10.8 & 12.0 & 11.4 & 11.3 & 10.5 & 10.4 \\
\hline FX liabilities to total liabilities & 15.1 & 14.2 & 15.1 & 17.8 & 18.6 & 18.1 & 16.8 & 15.3 \\
\hline Net open position in equities to capital & n.a. & n.a. & n.a. & n.a. & n.a. & n.a. & n.a. & n.a. \\
\hline \multicolumn{9}{|l|}{ Market liquidity } \\
\hline Average bid-ask spread in the securities market $3 /$ & n.a. & n.a. & n.a. & n.a. & n.a. & n.a. & n.a. & n.a. \\
\hline Average daily turnover ratio in the securities market & n.a. & n.a. & n.a. & n.a. & 7.0 & 7.7 & 5.4 & 3.4 \\
\hline \multicolumn{9}{|l|}{ Other financial corporations } \\
\hline Assets to total financial system assets & 35.2 & 36.6 & 37.8 & 37.6 & 38.1 & 36.4 & 32.8 & 35.5 \\
\hline Assets to GDP & 142.3 & 151.3 & 167.6 & 184.3 & 204.2 & 209.5 & 185.0 & 203.9 \\
\hline \multicolumn{9}{|l|}{ Households } \\
\hline Household debt to GDP & 36.4 & 37.8 & 40.0 & 43.0 & 45.5 & 48.0 & 49.9 & 52.4 \\
\hline Household debt service and principal payments to income & n.a. & 11.0 & 11.1 & 11.5 & 13.5 & 11.7 & 11.5 & 10.2 \\
\hline \multicolumn{9}{|l|}{ Real estate markets } \\
\hline Real estate prices & 10.1 & 12.4 & 16.0 & 14.8 & 9.9 & 5.7 & -3.0 & -4.4 \\
\hline Residential real estate loans to total loans & 65.7 & 67.1 & 69.1 & 71.2 & 73.4 & 74.7 & 75.7 & 75.8 \\
\hline Commercial real estate loans to total loans & n.a. & n.a. & n.a. & n.a. & n.a. & n.a. & n.a. & n.a. \\
\hline
\end{tabular}

Sources: Banque de France ; ACP ; BIS ; Ministère des Finances.

$1 /$ In percent of financial firms' gross operating surplus.

2/ Data cover interbank and customer lending to residents and nonresidents on a metropolitan basis.

$3 /$ Or in other markets that are most relevant to bank liquidity, such as foreign exchange markets.

4/ Other indicators such as additional balance sheet data (e.g. maturity mismatches in foreign currency), 
Table 8. France: Financial System Structure, 2000-09

\begin{tabular}{|c|c|c|c|c|c|c|c|c|c|c|}
\hline & 2000 & 2001 & 2002 & 2003 & 2004 & 2005 & 2006 & 2007 & $2008^{-}$ & $\frac{\text { Estimate }}{2009}$ \\
\hline \multicolumn{11}{|l|}{ Number } \\
\hline \multicolumn{11}{|l|}{ Banks } \\
\hline Commercial Banks & 362 & 357 & 345 & 333 & 326 & 316 & 313 & 312 & 310 & 302 \\
\hline Private & 354 & 352 & 341 & 329 & 323 & 312 & 309 & 308 & 307 & 299 \\
\hline Domestic & 140 & 144 & 142 & 138 & 139 & 131 & 131 & 130 & 136 & 137 \\
\hline Foreign & 214 & 208 & 199 & 191 & 184 & 181 & 178 & 178 & 171 & 162 \\
\hline State-owned 1/ & 8 & 5 & 4 & 4 & 3 & 4 & 4 & 4 & 3 & 3 \\
\hline Credit unions and mutuals & 154 & 148 & 136 & 129 & 127 & 125 & 121 & 111 & 105 & 102 \\
\hline \multicolumn{11}{|l|}{ Other credit institutions } \\
\hline Finance companies & 557 & 524 & 494 & 464 & 427 & 411 & 388 & 319 & 300 & 300 \\
\hline of which mortgage institutions & 3 & 4 & 4 & 4 & 4 & 4 & 4 & 4 & 5 & 7 \\
\hline Specialized financial institutions & 19 & 17 & 16 & 15 & 11 & 8 & 7 & 7 & 6 & 5 \\
\hline Municipal credit institutions & 22 & 21 & 21 & 21 & 21 & 21 & 20 & 19 & 18 & 19 \\
\hline Securities firms & 146 & 144 & 136 & 131 & 124 & 119 & 116 & 105 & 101 & 96 \\
\hline Insurance companies & 464 & 466 & 456 & 444 & 423 & 415 & 407 & 389 & 386 & 377 \\
\hline Life and retirement & 127 & 126 & 126 & 125 & 119 & 119 & 115 & 110 & 107 & 104 \\
\hline Non-life & 304 & 304 & 295 & 286 & 274 & 267 & 263 & 249 & 250 & 242 \\
\hline Reinsurance & 33 & 36 & 35 & 33 & 30 & 29 & 29 & 30 & 29 & 31 \\
\hline \multicolumn{11}{|l|}{ Concentration } \\
\hline Commercial Banks 2/ & 11 & 10 & 11 & 10 & 10 & 10 & 9 & 9 & 9 & 9 \\
\hline Securities companies $2 /$ & 3 & 3 & 3 & 4 & 3 & 2 & 2 & 2 & 2 & 2 \\
\hline Life insurance companies 2/ & n.a. & n.a. & n.a. & n.a. & n.a. & n.a. & n.a. & n.a. & n.a. & n.a. \\
\hline General insurance companies 2/ & n.a. & n.a. & n.a. & n.a. & n.a. & n.a. & n.a. & n.a. & n.a. & n.a. \\
\hline Pension funds $2 /$ & n.a. & n.a. & n.a. & n.a. & n.a. & n.a. & n.a. & n.a. & n.a. & n.a. \\
\hline Assets & \multicolumn{10}{|c|}{ (in billions of euros) } \\
\hline \multicolumn{11}{|l|}{ Banks } \\
\hline Commercial Banks & $2,145.0$ & $2,402.8$ & $2,359.7$ & $2,440.4$ & $2,861.7$ & $3,719.4$ & $4,283.9$ & $5,107.3$ & $5,468.9$ & 5188.3 \\
\hline Private & $2,123.0$ & $2,323.9$ & $2,277.7$ & $2,365.3$ & $2,850.4$ & $3,599.6$ & $4,159.3$ & $4,972.6$ & $5,343.8$ & 5004.5 \\
\hline Domestic & $1,681.5$ & $1,884.6$ & $1,865.7$ & $1,982.5$ & $2,428.5$ & $3,005.0$ & $3,558.9$ & $4,220.6$ & $4,510.2$ & 4180.4 \\
\hline Foreign & 441.5 & 439.3 & 412.0 & 382.8 & 421.9 & 594.6 & 600.4 & 752.0 & 833.6 & 824.1 \\
\hline State-owned 1/ & 22.0 & 78.8 & 82.1 & 75.1 & 11.3 & 119.7 & 124.6 & 134.7 & 125.0 & 183.8 \\
\hline Credit unions and mutuals & 847.7 & 857.4 & 880.8 & 934.7 & $1,053.5$ & $1,127.6$ & $1,259.0$ & $1,401.7$ & $1,598.5$ & 1674.7 \\
\hline \multicolumn{11}{|l|}{ Other credit institutions } \\
\hline Finance companies & 411.2 & 473.9 & 507.9 & 536.2 & 432.7 & 405.3 & 476.7 & 530.9 & 573.0 & 620.6 \\
\hline of which mortgage institutions & 50.9 & 62.3 & 75.9 & 91.9 & 107.2 & 125.7 & 148.6 & 186.0 & 199.2 & 216.7 \\
\hline Specialized financial institutions & 46.4 & 46.8 & 42.9 & 46.9 & 40.4 & 21.2 & 19.6 & 19.9 & 20.8 & 23.3 \\
\hline Municipal credit institutions & 1.8 & 1.9 & 1.9 & 1.9 & 1.9 & 1.7 & 1.3 & 1.2 & 1.2 & 1.2 \\
\hline Securities firms & 44.1 & 51.9 & 64.9 & 218.7 & 215.3 & 270.8 & 353.6 & 542.1 & 486.4 & 339.5 \\
\hline \multicolumn{11}{|l|}{ Insurance companies (assets) } \\
\hline Life and retirement & 749.7 & 798.3 & 832.4 & 907.3 & 985.2 & 1103.4 & 1125.4 & 1305.8 & 1242.3 & 1412.8 \\
\hline Non-life & 130.4 & 139.3 & 143.1 & 152.2 & 159.8 & 170.5 & 166.7 & 175.2 & 165.5 & 177.0 \\
\hline Reinsurance & 27.9 & 33.1 & 31.4 & 31.3 & 22.2 & 31.4 & 32.3 & 43.8 & 43.4 & 51.2 \\
\hline \multicolumn{11}{|l|}{ Deposits } \\
\hline \multicolumn{11}{|l|}{ Banks } \\
\hline Private commercial & 435.8 & 515.9 & 516.1 & 526.8 & 573.9 & 677.1 & 758.1 & 785.5 & 883.7 & 904.6 \\
\hline State-owned & 2.7 & 5.6 & 3.6 & 7.9 & 0.2 & 92.4 & 92.0 & 92.3 & 91.3 & 148.1 \\
\hline Foreign-owned subsidiaries & 44.2 & 50.8 & 52.7 & 47.7 & 45.2 & 56.6 & 58.9 & 86.2 & 83.5 & 63.4 \\
\hline Branches of foreign banks & 16.3 & 17.1 & 19.4 & 20.9 & 19.7 & 26.1 & 24.8 & 30.9 & 27.3 & 28.8 \\
\hline
\end{tabular}

1/ Including development banks. Nonbank development finance corporations should be included separately under "Other credit institutions."

2/ Number of institutions with 75 percent of total assets 
INTERNATIONAL MONETARY FUND

FRANCE

Staff Report for the 2010 Article IV Consultation-Informational Annexes

Prepared by the European Department

July 13,2010

The discussions for the 2010 Article IV consultation were held in Paris during

June 2-14, 2010. The concluding statement of the mission is available at http://www.imf.org/external/np/ms/2010/061510.htm.

Staff team: Ms. Gulde-Wolf (head), Mr. De Vrijer, Mr. Cheng, Ms. Tytell, Ms. Xiao (all EUR), and Ms. Yakadina (FAD).

Country interlocutors: Mrs. Lagarde, the Minister of Economy, Industry, and Employment; Mr. Baroin, the Minister of the Budget, the Civil Service, and the Reform of the State; Mr. Woerth, the Minister for Employment, Social Affairs and the Pension Reform; Mr. Redouin, Deputy Governor of the Banque de France, and his staff; the deputy secretary general of the presidency; the director general of the treasury; the directors of the budget, taxation, labor and social affairs, and their staffs; the deputy chief of staff in the cabinet of the Prime Minister; members of the finance commissions of the National Assembly and the Senate; INSEE; the Prudential Supervision Authority (ACP); the Financial Market Authority (AMF); the French Banking Federation (FBF); the Competition Authority; the Pensions Advisory Council (COR); and representatives of labor unions, employer organizations, and the financial sector. Mr. Fayolle (Executive Director) or Mr. Ducrocq (Alternate Executive Director) attended the meetings.

Fund relations: The previous Article IV consultation took place on July 29, 2009. France accepted the obligations under Article VIII and maintains an exchange system free of restrictions, except for certain exchange measures imposed for security reasons in accordance with the relevant EU regulations and UN Security Council resolutions.

Data: France subscribes to the Fund's Special Data Dissemination Standard, and comprehensive economic data are available on a timely basis. 


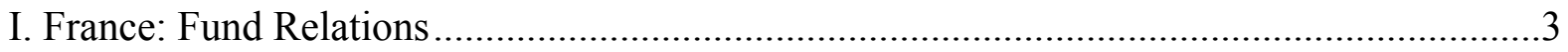

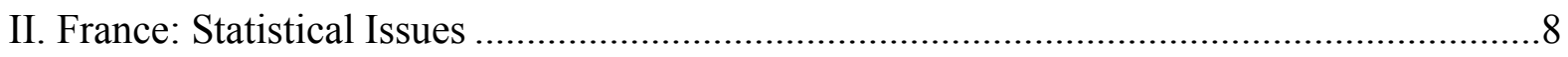

III. France: Table of Common Indicators Required for Surveillance ....................................9 


\section{France: Fund Relations}

(As of May 31, 2010)

I. Membership Status: Joined December 27, 1945; Article VIII.

II. General Resources Account:

Quota

Fund holdings of currency

Reserve position in Fund

III. SDR Department:

Net cumulative allocation

Holdings
SDR Million

$\begin{array}{cc}10,738.50 & \text { Percent of Quota } \\ 8,185.34 & 100.00 \\ 2,553.34 & 76.22 \\ & 23.78\end{array}$

SDR Million Percent of Allocation

$10,134.20$

100.00

$9,719.09$

95.90

IV. Outstanding Purchases and Loans: None

V. Latest Financial Arrangements: None

VI. Projected Payments to Fund (SDR million; based on existing use of resources and present holdings of SDRs):

Principal

Forthcoming
$\underline{2010} \quad \underline{2011} \quad \underline{2012} \quad \underline{2013} \quad \underline{2014}$

Charges/interest

Total

$\frac{0.53}{0.53} \quad \frac{1.12}{1.12} \quad \frac{1.21}{1.21} \quad \frac{1.21}{1.21} \quad \frac{1.21}{1.21}$

VII. Implementation of HIPC Initiative: Not applicable

VIII. Safeguards Assessments: Not applicable

IX. Exchange Rate Arrangements:

- France's currency is the euro, which floats freely and independently against other currencies.

- In accordance with EU regulations and the relevant UN Security Council resolutions, certain restrictions are maintained on the making of payments and transfers for current international transactions with respect to the former government of Iraq, the former government of Liberia, Myanmar, certain individuals associated with the previous government of the former Republic of Yugoslavia, and Zimbabwe. Financing of, and financial assistance related to, military activities in the Democratic Republic of the Congo (from October 1, 2003), Somalia (effective January 27, 2003), and Sudan (from January 26, 2004) are prohibited. Restrictions also apply on transfers with respect 
to the Taliban and individuals and organizations associated with terrorism. The restriction with respect to the Socialist People's Libyan Arab Jamahiriya has been notified to the Fund under Decision No. 144-(52/51).

- Measures have been taken to freeze accounts of listed persons and entities linked to terrorists pursuant to the relevant EU regulations and UN Security Council resolutions.

\section{Article IV Consultation:}

The last Article IV consultation was concluded on July 31, 2009. The associated Executive Board assessment is available at http://www.imf.org/external/np/sec/pn/2009/pn0996.htm and the staff report at http://www.imf.org/external/pubs/ft/scr/2009/cr09232.pdf. France is on the standard 12-month consultation cycle.

\section{FSAP Participation and ROSC:}

France-Report on the Observance of Standards and Codes (ROSC): Module I-Fiscal Transparency

\author{
Fiscal Transparency-Update
}

Fiscal Transparency-Update
October 17,2000

IMF Country Report

No. 01/196, 11/05/01

IMF Country Report

No. $04 / 345,11 / 03 / 04$

Summary: The report found that France has achieved a high level of fiscal transparency and has introduced a number of improvements in coverage and presentation of fiscal information. Notable areas of progress include the development in the final accounts publication to include more complete information on government assets and liabilities as well as disclosure of contingent liabilities. Accounting standards have been changed to reflect accruals principles in a number of areas, and these standards are clearly explained. The staff suggested that further steps could be taken to identify and report quasi-fiscal activities in the budget presentation, provide a more consolidated picture of fiscal activity outside the appropriation process, and improve the reconciliation of stated policies with outcomes at the general government level.

These issues have been addressed in the Loi organique aux lois de finance (LOLF), which has become fully effective on January 1, 2006. In addition to the annual appropriations, the first multi-annual fiscal framework law was adopted in January 2009, and contains fiscal objectives for the period 2009-12. The budget is organized along missions and provides details on the level of appropriations for each mission and performance indicators by which the expected results of the mission will be assessed ex post. The State Audit Office has been 
given the new assignment of certifying the public accounts, and implementation of accrualsbasis accounting has been confirmed. Parliamentary oversight powers have been strengthened.

France-Report on the Observance of Standards and Codes $\quad$ October 2000, corrected: (ROSC): Module II-Transparency in Monetary and Financial 2/15/01 Policies

Transparency in Monetary and Financial Policies-Update

Transparency in Monetary and Financial Policies-Update
IMF Country Report No. $01 / 197,11 / 05 / 01$

IMF Country Report No. $02 / 248,11 / 13 / 02$

Summary: The 2000 ROSC noticed that transparency of financial policies is accorded a high priority by all financial agencies assessed, and they are in observance of the good practices of the Code of Good Practices on Transparency in Monetary and Financial Policies. The major agencies disclose their objectives, their legal and institutional frameworks, and have open processes of policymaking and regulation. The principles of transparency are observed by dissemination of relevant information to the public and in the agencies' arrangements for internal conduct, integrity, and accountability. However, the staff noted that the framework for supervision and regulation applicable to mutual insurance firms is not as well defined and suggested to improve its transparency. The transparency of monetary policy was not assessed by the Fund team as the Banque de France is a member of the European System of Central Banks and no longer conducts independent monetary policy.

Subsequently, the framework for supervision and regulation applicable to a specific group of mutual insurance firms was modified in a number of steps. In August 2003, legislation created a single supervisory body, the Commission de Contrôle des Assurances, Mutuelles et Institutions de Prévoyance (CCAMIP) by merging the regular insurance supervisor (CCA) and mutualities' supervisor (CCMIP). Coordination with the banking sector supervisors was strengthened and the powers of the supervisory authorities extended.

France-Report on the Observance of Standards and Codes (ROSC): Data Module

Data Module-Update

Data Module-Update
IMF Country Report

No. $03 / 339,10 / 2903$

IMF Country Report

No. $04 / 345,11 / 03 / 04$

IMF Country Report

No. 05/398, 11/07/05 
Summary: The report found that France is in observance of the Fund's Special Data Dissemination Standard (SDDS). In particular, the mandate of INSEE and the Banque de France for the production of the six macroeconomic datasets is clearly defined, with the reporting burden and the confidentiality provisions given special consideration notably through the CNIS. Professionalism is central to the statistical operations of the two institutions, internationally and/or European accepted methodologies are generally followed, the degree of accuracy and reliability of the six datasets is remarkable, statistics are relevant and provided on a timely basis, and they are accessible to the public.

The report made a number of suggestions for further improvements: the responsibility of INSEE as the producer of government finance statistics should be clarified; data sharing between the Banque de France and the rest of the French statistical system improved; classification and valuation methods in balance-of-payments statistics reviewed; consistency between the current account of the balance of payments and the goods and services account in the national accounts improved; the timing of revisions in the quarterly and annual national accounts aligned; and identification of data production units of INSEE facilitated.

France continues to implement several of the 2003 ROSC Data Module recommendations, including by promoting a broader understanding of statistical data revisions, making greater use of firm-level data to improve the measurement of changes in stocks, and intensifying work on portfolio investment income with the objective of starting to record those transactions on an accrual basis.

France-Financial System Stability Assessment (FSSA) IMF Country Report No. $04 / 344,11 / 03 / 04$

FSAP Assessment and Reports on ROSCs IMF Country Report No. $04 / 345,11 / 03 / 04$

FSAP Assessment IMF Country Report No. $05 / 185,06 / 08 / 05$

\section{Publication of FSAP_Detailed Assessment of Observance of IMF Country Report Standards and Codes No. $05 / 186,06 / 08 / 05$}

Summary: The report concluded that France's financial sector is strong and well supervised. No weaknesses that could cause systemic risks were identified. The strength of the system is supported by the financial soundness indicators and the strong conformity to the supervisory and regulatory standards approved by the Basel Committee, IAIS, IOSCO, FATF, and CPSS.

The degree of observance of the transparency code is high in all relevant areas. The French banking sector has been modernized and restructured over the past two decades and is well 
capitalized. Systemic vulnerabilities in the important insurance sector are well contained. Securities markets are large and sophisticated.

Notwithstanding the strengths of the French financial sector, a number of issues emerged from the FSAP, including (i) concentration in banking may have reached a point where further consolidation could intensify concerns over the scope for collusion and long-term stability where many banks could be considered "too big to fail;" (ii) banks' large and growing portfolios of fixed-rate residential housing loans could represent a longer-term risk in the event of large increases in funding costs and/or a significant fall in real estate prices; (iii) some administered savings schemes and other policy measures give rise to costs and impede financial market innovation. These schemes are not well targeted to achieve intended social goals and are not well aligned with current priorities, such as strengthening the pension system; (iv) the banking system's rapid accumulation of capital strengthens banks' resilience.

This accumulation is harder to control for mutual banks, given their legal restrictions on remuneration of their members. And, for all banks, it could encourage expansion through expensive takeovers and risky new ventures; (v) the supervisory system of the financial sector is composed of specialized segments. Coordination mechanisms need to be further adapted. Additional steps should be considered in the future as cross-sectoral financial groups become more prevalent; (vi) the consolidation of the French stock and futures markets with others in Europe has increased the importance of effective cooperation across national jurisdictions. Moreover, the authorities face the challenge of adjusting to and effectively implementing the significant regulatory overhaul that took place in late 2003; and (vii) the infrastructure for the clearing and settlement of payments and securities is generally sound and modern. However, there is some room for improvement in the clearing and settlement of retail payments and securities, where the multilateral netting systems lack fully adequate safeguards to ensure timely settlement in case of default. 


\section{FRANCE: STATISTICAL ISSUES}

The economic database is comprehensive and of high quality, and data provision to the Fund is adequate for surveillance. The authorities regularly publish a full range of economic and financial data, and calendar dates of main statistical releases are also provided. France subscribes to the Fund's Special Data Dissemination Standard. The transmission of data in electronic form from INSEE (Institut national de la statistique et des études économiques) and the profusion of data from various institutions (Banque de France, INSEE, ministry of finance, ministry of labor and solidarity) have helped to build an infrastructure, in which all data can be easily accessed through the Economic Data Sharing System. A data ROSC mission conducted an assessment of the statistical system in March 2003, and the report was published in October 2003. A factual update to the main report was published in November 2004.

France's monetary and banking statistics methodology conforms with the European Central Bank framework, which provides comparable details as the Standardized Report Forms developed by STA. Statistics for International Financial Statistics on banking institutions and monetary aggregates are prepared on a monthly basis and are timely. Monetary data are also disseminated in the quarterly IFS Supplement on monetary and financial statistics.

France follows the European System of Integrated Economic Accounts 1995 (ESA95). Data for GDP and its expenditure components are available from 1978 onwards. Both annual and quarterly accounts provide reliable information, although estimates from the two accounts differ slightly before the quarterly accounts are revised to be aligned to the annual ones. In 2005 , national accounts estimates were rebased to 2000 prices.

Government finance statistics have been strengthened recently. Both central and general government data are presented in a more comprehensive fashion than previously and the data for 2006 and 2007 also reflect the various impacts of recent budgetary reform. Although the source data is collected by the Ministry of Economy and Finance, INSEE is principally responsible for the compilation and dissemination of fiscal data in a framework that is consistent with ESA95. INSEE's website has recently been enhanced; in particular, it includes expenditure tables and government revenues by subsector (central government, miscellaneous central government agencies, local governments, and social security administration).

Balance-of-payments statistics should be interpreted with caution, given large errors and omissions. Greater coherence between the external current account and the rest of the world account in the national accounts is needed. In this regard, work with promising early results has been undertaken on the transportation account. 


\section{FRANCE: TABLE OF COMMON INDICATORS REQUIRED FOR SURVEILLANCE}

(As of June 30, 2010)

\begin{tabular}{|c|c|c|c|c|c|}
\hline & $\begin{array}{c}\text { Date of } \\
\text { Latest } \\
\text { Observatio } \\
n \\
\end{array}$ & $\begin{array}{l}\text { Date } \\
\text { Received }\end{array}$ & $\begin{array}{c}\text { Frequency } \\
\text { of } \\
\text { Data }\end{array}$ & $\begin{array}{l}\text { Frequenc } \\
\text { y of } \\
\text { Reporting }\end{array}$ & $\begin{array}{l}\text { Frequency } \\
\text { of } \\
\text { Publication }\end{array}$ \\
\hline Exchange Rates & $05 / 10$ & $06 / 10$ & Monthly & Monthly & Monthly \\
\hline $\begin{array}{l}\text { International Reserve Assets and Reserve Liabilities of } \\
\text { the Monetary Authorities }{ }^{1}\end{array}$ & $05 / 10$ & $06 / 10$ & Monthly & Monthly & Monthly \\
\hline International Investment Position & 2009 & Q1:2010 & Annual & Annual & Annual \\
\hline Reserve/Base Money & $05 / 10$ & $06 / 10$ & Monthly & Monthly & Monthly \\
\hline Broad Money & $05 / 10$ & $06 / 10$ & Monthly & Monthly & Monthly \\
\hline Central Bank Balance Sheet & $05 / 10$ & $06 / 10$ & Monthly & Monthly & Monthly \\
\hline Consolidated Balance Sheet of the Banking System & $05 / 10$ & $06 / 10$ & Monthly & Monthly & Monthly \\
\hline Interest Rates ${ }^{2}$ & $05 / 10$ & $06 / 10$ & Monthly & Monthly & Monthly \\
\hline Consumer Price Index & $05 / 10$ & $06 / 10$ & Monthly & Monthly & Monthly \\
\hline $\begin{array}{l}\text { Revenue, Expenditure, Balance and Composition of } \\
\text { Financing }{ }^{3} \text {-General Government }{ }^{4}\end{array}$ & Q1:2010 & $06 / 10$ & Quarterly & Quarterly & Quarterly \\
\hline $\begin{array}{l}\text { Revenue, Expenditure, Balance and Composition of } \\
\text { Financing }^{3} \text { - Central Government }{ }^{5}\end{array}$ & $04 / 10$ & $05 / 10$ & Monthly & Monthly & Monthly \\
\hline Stock of Central Government Debt & $05 / 10$ & $06 / 10$ & Monthly & Monthly & Monthly \\
\hline Stock of Central Government-Guaranteed Debt & Q1:2010 & $06 / 10$ & Quarterly & Quarterly & Quarterly \\
\hline External Current Account Balance & Q1:2010 & $06 / 10$ & Quarterly & Quarterly & Quarterly \\
\hline Exports and Imports of Goods and Services & Q1:2010 & $06 / 10$ & Quarterly & Quarterly & Quarterly \\
\hline GDP/GNP & Q1:2010 & $06 / 10$ & Quarterly & Quarterly & Quarterly \\
\hline Gross External Debt & Q1:2010 & $06 / 10$ & Quarterly & Quarterly & Quarterly \\
\hline
\end{tabular}




\section{INTERNATIONAL MONETARY FUND}

\section{FRANCE}

\section{Staff Report for the 2010 Article IV Consultation}

\section{Supplementary Information}

Prepared by the Staff Representatives for the 2010 Consultation with France

Approved by Ajai Chopra and Martin Mühleisen

July 27,2010

1. This supplement provides an update of economic and policy developments since the release of the staff report (7/14/10). The thrust of the staff appraisal remains unchanged.

2. Recent data confirm a continuing gradual recovery. Industrial production in May increased more-than-expected by 1.7 percent and exports expanded further, but new orders declined. In June, household consumption of manufactured goods fell with durable goods consumption shrinking by 1.8 percent (month-on-month and seasonally adjusted). House prices appear to have broadly stabilized in recent months as the demand for new dwellings has increased. Business confidence further improved in July, reaching its highest level since a year ago, but consumer confidence moved sideways amid concerns about the high unemployment rate.

3. The pension reform is moving ahead. The draft law on pension reform passed the Social Affairs Committee of the National Assembly on July 21, with debate in the full National Assembly slated immediately after the summer recess in early September. The Committee made no material changes to the government's reform proposals, including the gradual raise of the retirement age. This is a welcome step towards implementation of this important and difficult reform that aims to re-establish financial equilibrium in the pension system by 2018 .

4. The working group on fiscal rules presented a proposal for a new, strengthened multi-year budgetary framework, enshrined in the constitution. ${ }^{1}$ A new multi-year budget framework law would include a binding trajectory towards a zero structural deficit and reinforce national ownership of the fiscal objectives set forth in France's Stability Programs. The budget framework law would define both a revenue floor and an expenditure

\footnotetext{
${ }^{1}$ The working group is chaired by Mr. Camdessus and its final report was presented on June 21, 2010.
} 
ceiling for the central government and the social security administrations, also encompassing operations of some general-government entities currently off-budget. The revenue and spending rules set in the budget framework law will be enforced by the Constitutional Council and would be binding for the annual budget laws. A system of notional accounts, as in Germany, would help the adjustment over two subsequent budget years in case of deviation from the rules. In parallel, limits would be set on the resources transferred to the constitutionally independent local governments that are already subject to a golden rule. Moreover, a constitutional amendment would cement recent administrative measures to prohibit any revenue-reducing initiatives outside of the respective budget laws for the central government and the social security administration. The working group also calls for the creation of an independent fiscal council, in order to increase the realism of the macroeconomic assumptions underlying the budgetary framework and to strengthen the government's accountability. Staff supports the recommendations of the working group which, if implemented, would be instrumental in restoring balance in public finances.

5. The EU-wide stress test results released on July 23 have confirmed the resilience of French banks. The four major banking groups participating in the stress test represent about 80 percent of the French banking system. The French benchmark macroeconomic scenario assumes real GDP growth of 1.2 percent in 2010 and 1.5 percent in 2011, both below staff's baseline scenario. The adverse macroeconomic scenario assumes real GDP growth of 0.7 percent in 2010 and -0.1 percent in 2011 . In addition to the adverse scenario, a shock was applied to sovereign exposures in banks' trading books and loans to the private sector in their banking books. The stress scenario-adverse macroeconomic scenario coupled with the sovereign shock - reduces the average Tier 1 ratio of French banks by 165 basis points relative to the benchmark level of 9.3 percent at end-2011, which is only 60 basis points below the actual end-2009 level. The impact on Tier 1 capital of the shock to sovereign exposures is only 16 basis points on average with small variation among banks. The Tier 1 ratio of individual banks under the stress scenario ranges from 8.5 to 10 percent, well above the 6 percent threshold used in the test.

\section{The publication of the stress test results, in combination with the full disclosure} of the sovereign holdings of French banks are helpful steps toward better transparency. As argued in the staff report, steps in this direction may help the market's assessment of French banks. In addition to Europe-wide coordinated efforts, France should - as recommended in the staff report - continue with appropriate national efforts. 


\section{INTERNATIONAL MONETARY FUND}

\section{Public Information Notice}

Public Information Notice (PIN) No. 10/103 FOR IMMEDIATE RELEASE

July 29, 2010
International Monetary Fund $70019^{\text {th }}$ Street, NW

Washington, D. C. 20431 USA

\section{IMF Executive Board Concludes 2010 Article IV Consultation with France}

On July 28, 2010, the Executive Board of the International Monetary Fund (IMF) concluded the Article IV consultation with France. ${ }^{1}$

\section{Background}

A fragile recovery is underway in France. The recession was less severe in France than in most other advanced economies, reflecting the comparatively low trade openness, fairly resilient financial sector, large social safety nets, and timely and decisive government intervention. Nonetheless, the unemployment rate has risen steeply, notably among the young. The financial crisis and economic downturn have exerted a significant toll on public finances, and in the financial sector concerns remain about asset quality, and possible spillovers from mature markets.

The authorities have taken important policy actions to stabilize the financial system and have implemented a suitable fiscal stimulus to cushion the downturn. With the recovery underway, the policy focus is shifting from crisis management to strengthening the foundations of the economy through fiscal consolidation, supporting the full recovery of the

\footnotetext{
${ }^{1}$ Under Article IV of the IMF's Articles of Agreement, the IMF holds bilateral discussions with members, usually every year. A staff team visits the country, collects economic and financial information, and discusses with officials the country's economic developments and policies. On return to headquarters, the staff prepares a report, which forms the basis for discussion by the Executive Board. At the conclusion of the discussion, the Managing Director, as Chairman of the Board, summarizes the views of Executive Directors, and this summary is transmitted to the country's authorities. An explanation of any qualifiers used in summings up can be found here: http://www.imf.org/external/np/sec/misc/qualifiers.htm.
} 
financial system and improving financial regulation. The authorities are also implementing structural reforms to raise potential growth, create jobs, and strengthen competitiveness.

In light of the sharply increased public debt and the turbulence on European financial markets, the authorities are firmly committed to strong fiscal adjustment beginning in 2011, and to reduce the overall fiscal deficit to 3 percent of gross domestic product (GDP) by 2013. The fiscal stimulus is set to expire by end-2010. Revenue and expenditure measures that have already been announced are sizable and would reduce the deficit by some 2 percentage points in 2011. However, further measures at all levels of government are needed to achieve the envisaged fiscal consolidation over the medium term. In June, a major pension reform was announced that is to be legislated in the coming months. The reform would gradually increase the effective retirement age and aims to achieve financial equilibrium in the pension system by 2018 .

French banks are emerging relatively stronger from the global financial crisis and a gradual exit from crisis-related government support is underway. The EU-wide stress test results released on July 23 have confirmed the resilience of French banks. The new supervisory structure that merges banking and insurance supervision responds to the need for systemic supervision while measures to control financial sector remuneration aim to reduce incentives for excessive risk-taking. The regulatory reform will be completed by the planned creation of a systemic risk board with participation of all relevant supervisors and government bodies. However, increases in nonperforming loans as a result of the recession and possible spillovers from the European sovereign debt crisis may exert renewed pressure on the financial sector and constrain lending growth. On the structural front, the authorities continue to implement their ambitious reform agenda, particularly in the labor and product markets, with a view to boosting job creation, increasing growth, and strengthening competitiveness.

The French economy is expected to recover gradually. Real GDP is projected to grow by 1.4 percent in 2010 and 1.6 percent in 2011, somewhat faster than in the Euro Area as a whole. The same features of the French economy that partly shielded it during the recession are also likely to slow the pace of the recovery. Risks to the outlook are slanted to the downside. Lingering concerns about sovereign risks in the Euro Area could dampen confidence, increase financing costs, and depress demand.

\section{Executive Board Assessment}

Executive Directors noted that the French economy weathered the global crisis better than most of its peers. The timely government intervention succeeded in stabilizing the financial system and cushioning the downturn. Directors noted that the outlook is challenging and that growth is expected to pick up only gradually. Unemployment and public debt are relatively high; the imminent fiscal consolidation in France and most European countries will 
weigh on demand; and lingering concerns about sovereign risks call for continued vigilance. A vigorous implementation of the authorities' reform agenda will be needed to support the recovery.

Directors considered the fiscal stimulus in 2009-10 to be well designed, including the abolition of the local business tax. Given the sharply increased public debt, the focus in the years ahead should be on a significant and credible fiscal consolidation. Directors commended the authorities' determination to reduce the overall fiscal deficit to 3 percent of GDP by 2013. They welcomed the already specified consolidation measures, including continued spending restraint in the central government and a nominal freeze of transfers to local governments. The announced pension reform is a key component of the consolidation strategy and rightly emphasizes an increase in the retirement age. Efforts to better control healthcare spending should also be pursued.

Directors noted that beyond the measures to meet the fiscal target for 2011, further steps, including contingency measures, will be needed to achieve the medium-term objectives. To enhance the credibility of the consolidation effort, Directors stressed the importance of ensuring that the multiyear budget framework is based on realistic macroeconomic assumptions, and saw merit in proposals for the establishment of an independent council and the adoption of a fiscal rule.

Directors observed that the French banks are emerging from the crisis with improving profitability, and welcomed the confirmation of the resilience of the French banks by the Europe-wide stress test results. They noted that the communication of key exposures helps transparency and allows for a better assessment of financial sector stability. A sluggish recovery and relatively high exposures to peripheral Europe may pose new risks, including for asset quality. Although these risks appear manageable, they require continued strong supervision. Directors recommended that the authorities should be prepared to take appropriate additional measures to support banks, if needed. They welcomed the recent unification of banking and insurance supervision and encouraged France to continue to play an active role in promoting international regulatory reforms.

Directors stressed the importance of pressing ahead with the structural reform agenda, in order to strengthen competitiveness, boost job creation and promote innovation. In addition to labor market activation and training policies, minimum wage moderation should continue to gradually establish a motivating pay scale for young and low-skilled workers. For senior workers, efforts to improve incentives for continued work, including effective job-search requirements, need to be pursued in tandem with the pension reform. Directors encouraged further steps to improve product and services market flexibility. 
Public Information Notices (PINs) form part of the IMF's efforts to promote transparency of the IMF's views and analysis of economic developments and policies. With the consent of the country (or countries) concerned, PINs are issued after Executive Board discussions of Article IV consultations with member countries, of its surveillance of developments at the regional level, of post-program monitoring, and of ex post assessments of member countries with longer-term program engagements. PINs are also issued after Executive Board discussions of general policy matters, unless otherwise decided by the Executive Board in a particular case. The staff report (use the free Adobe Acrobat Reader to view this pdf file) for the 2010 Article IV Consultation with France is also available. 
France: Selected Economic and Social Indicators, 2007-15

Projections

$\begin{array}{lllllllll}2007 & 2008 & 2009 & 2010 & 2011 & 2012 & 2013 & 2014 & 2015\end{array}$
Real economy (change in percent)

Real GDP

Domestic demand

CPI (year average)

Unemployment rate (in percent)

Gross national savings (percent of GDP)

Gross domestic investment (percent of GDP)

Public finance (percent of GDP)

Central government balance

General government balance

Structural balance (percent of potential GDP)

Primary balance

General government gross debt $1 /$

Money and interest rates (in percent)

Money market rate 2/

Government bond yield 2/

Balance of payments (in percent of GDP)

Exports of goods

Volume growth (in percent)

Imports of goods

Volume growth (in percent)

Trade balance

Current account

FDI (net)

Official reserves (US\$ billion)

Fund position (as of May 31, 2010)

Holdings of currency (percent of quota)

Holdings of SDRs (percent of allocation)

Quota (SDRs million)

\section{Exchange rates}

Euro per U.S. dollar 2/

Nominal effective rate $(2000=100)$

Real effective exchange rate $(2000=100)$

$\begin{array}{rrrrrrrrr}2.3 & 0.1 & -2.5 & 1.4 & 1.6 & 1.8 & 2.0 & 2.1 & 2.1 \\ 3.3 & 0.4 & -2.4 & 1.1 & 1.5 & 1.7 & 1.9 & 2.1 & 2.1 \\ 1.6 & 3.2 & 0.1 & 1.3 & 1.6 & 1.8 & 1.9 & 1.9 & 1.9 \\ 8.4 & 7.8 & 9.5 & 10.0 & 10.1 & 9.7 & 9.2 & 8.7 & 8.4 \\ 21.2 & 19.8 & 16.7 & 17.9 & 18.5 & 18.7 & 18.9 & 19.1 & 19.3 \\ 22.2 & 22.0 & 19.0 & 19.5 & 19.9 & 20.1 & 20.2 & 20.4 & 20.6\end{array}$

$\begin{array}{rrrrrrrrr}-2.1 & -2.8 & -6.2 & -5.6 & -3.6 & -2.3 & -1.4 & -0.6 & 0.2 \\ -2.7 & -3.3 & -7.5 & -8.0 & -6.1 & -4.8 & -3.9 & -3.2 & -2.4 \\ -3.2 & -3.1 & -5.0 & -4.9 & -3.7 & -3.0 & -2.6 & -2.4 & -2.0 \\ 0.0 & -0.5 & -5.2 & -5.4 & -3.3 & -1.9 & -1.0 & -0.1 & 0.7 \\ 63.8 & 67.5 & 78.1 & 84.3 & 87.8 & 89.7 & 90.3 & 90.1 & 89.1\end{array}$

$\begin{array}{lllllllll}4.0 & 3.8 & 1.0 & 0.7 & \ldots & \ldots & \ldots & \ldots & \ldots \\ 4.3 & 4.2 & 3.6 & 3.5 & \ldots & \ldots & \ldots & \ldots & \ldots\end{array}$

$\begin{array}{lllllllll}21.1 & 21.1 & 17.8 & 20.7 & 20.8 & 20.9 & 21.0 & 21.1 & 21.1\end{array}$

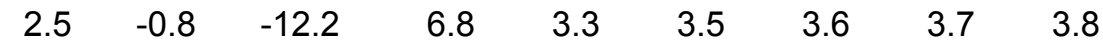

$\begin{array}{rrrrrrrrr}23.2 & 24.1 & 20.2 & 22.7 & 22.7 & 22.6 & 22.6 & 22.7 & 22.8\end{array}$

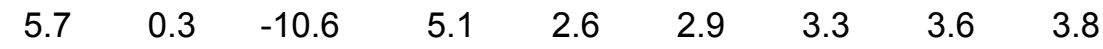

$\begin{array}{lllllllll}-2.1 & -3.0 & -2.5 & -1.9 & -1.8 & -1.7 & -1.7 & -1.6 & -1.6\end{array}$

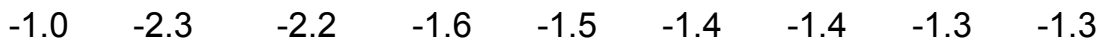

$\begin{array}{lllllllll}-2.5 & -3.6 & -3.8 & -2.3 & -2.2 & -2.1 & -2.0 & -1.9 & -1.8\end{array}$

$\begin{array}{llllllllll}45.7 & 33.6 & 46.6 & \ldots & \ldots & \ldots & \ldots & \ldots & \ldots\end{array}$

76.2

95.9

10,739

$\begin{array}{rrrr}0.73 & 0.68 & 0.72 & 0.76 \\ 102.4 & 104.9 & 104.3 & \ldots \\ 103.2 & 105.3 & 101.0 & \ldots\end{array}$


Potential output and output gap

Potential output

Output gap

$\begin{array}{rrrrrrrrr}2.1 & 1.6 & 1.1 & 1.1 & 1.1 & 1.2 & 1.2 & 1.3 & 1.4 \\ 1.1 & -0.4 & -3.9 & -3.6 & -3.0 & -2.4 & -1.7 & -0.9 & -0.2\end{array}$

Social indicators

Per capita GDP (2006): US\$35,471; Life expectancy at birth (2006): 77.2 (male) and 84.1 (female);

Poverty rate (2005): 12.1 percent (60 percent line), 6.3 percent (50 percent line);

Income distribution (ratio of income received by top and bottom quintiles, 2004): 4.2.

Sources: French authorities; IMF staff estimates and projections.

$1 /$ The debt figure does not include guarantees on nongeneral government debt.

2/ For 2010, average for January-March. 


\section{Statement by Mr. Ambroise Fayolle, Executive Director for France \\ July 28, 2010}

We wish to thank staff for a comprehensive set of papers, which depict well the policy challenges faced by France. The discussions with the mission were frank and very much appreciated by my authorities, and provided useful input to policy formulation. The mission was also an opportunity to follow-up on several recommendations made last year by the Executive Board, such as the reduction in tax expenditures, the freeze in expenditures at the level of the central government, and the launch of an ambitious pension reform which are all being implemented.

At this critical juncture, the French authorities have clearly indicated their strong commitment to fiscal consolidation so as to ensure long-term sustainability, as well as their resolution to maintain the momentum of structural reforms with a view to increasing competitiveness and potential growth. They consider these two pillars of the economic strategy as mutually reinforcing.

\section{Outlook: the recovery is gaining strength.}

The French economy has weathered the crisis relatively well compared to its peers. The fiscal stimulus, complemented by the full effect of the sizeable automatic stabilizers, helped maintain private consumption in positive territory throughout the crisis, and the economy exited recession during the second quarter of 2009. The financial sector proved fairly resilient and benefited from an appropriately targeted support, which has now been almost entirely phased out. Structural features of the economy also contributed to soften the impact of the shock, as mentioned by staff.

The recovery is now underway and my authorities agree with staff's growth forecast for 2010 at 1.4 percent. Activity is rebounding faster than the euro area average and is driven by private consumption, net exports, and a turn in the inventory cycle. The depreciation of the euro, by 7.7 percent in nominal effective terms between November 2009 and June 2010, is also expected to bolster the recovery during the second half of the year.

Staff's forecasts seem, however, rather pessimistic on the growth outlook for 2011. Indeed, while consumption is expected to remain solid, my authorities foresee that private investment, which has not yet recovered, will bring a significant contribution to growth in 2011. Short-term indicators from business surveys already suggest a recovery in investment, and the conventional accelerator effect should gather steam. This forecast for private investment is also underpinned by the level of interest rates, which is expected to remain low, and the positive effects of the removal of the local business tax. Besides, my authorities believe that downside risks should be nuanced, as recent data suggest, e.g., that credit growth has ceased to slowdown. 
My authorities are more sanguine than staff about the impact of the crisis on potential growth. They estimate French potential growth at 1.7 percent per year over the medium term (2009-13). While staff rightly indicates that this divergence of views is mainly related to the foreseen impact of the crisis on total factor productivity growth - which is indeed ambiguous - we would also stress that the crisis had slightly different features in France, and in particular a less disruptive effect on the financial sector and on households' balance sheets. Besides, we expect that the pension reform will gradually translate into a higher rate of activity, as it was the case following previous waves of reforms (the employment rate in the 55-64 years bracket has already been raised by 3.6 percentage points since 2002).

\section{A strong commitment to fiscal sustainability}

The global crisis and the large fiscal impulse led to a sharp deterioration of the French public finances, calling for an ambitious fiscal consolidation. The cost of financing for the Treasury remains at historically low levels (2.9 percent for 10-year bonds) due to flight to quality effects. However, recent events in Europe triggered a heightened awareness of risks to debt sustainability.

In this context, the government is firmly committed to undertaking a large and durable fiscal consolidation starting in 2011. The French stability program will bring the deficit down from 8 percent of GDP in 2010 to 6 percent in 2011, and aims at returning to 3 percent of GDP by 2013. Half of the adjustment in 2011 will come from structural savings, the rest being provided by the phasing out of the stimulus and the recovery of tax revenues. The complete package of measures to secure the announced deficit path will be finalized by September.

In line with IMF recommendations, and consistently with the comprehensive diagnostic of France's public finances which has been realized beforehand, my authorities intend to achieve most of the consolidation over the 2011-13 period through expenditures cuts, as explained in paragraph 16 of the report. All levels of government (central, local, and the social security system) will contribute to this effort to ensure fiscal sustainability.

The recently announced pension reform is a key element of the fiscal consolidation strategy. Relying mainly on the gradual increase in the legal retirement age from 60 to 62 and the legal minimum age of full pension entitlement from 65 to 67, this major reform will eliminate the deficit associated with the pension system by 2018 and bring France in line with the main comparator countries. The reform will considerably improve medium-term fiscal sustainability without affecting labor cost and will also have an immediate impact on tax revenue, since it is partly financed with a moderate increase in taxation of investment income. As for the residual deficits during the transition period, they will be financed by the 
Reserve Fund of the pension system (Fonds de reserve des retraites), which has accumulated over $€ 33$ billion of assets. All other things being equal, the reform will reduce the general government deficit by 0.5 point of GDP in 2013 and 1.2 point by 2020 , and will save close to 10 points in the gross public debt-to-GDP ratio through the period.

This consolidation effort is also underpinned by several structural reforms aiming at strengthening fiscal discipline. The multiyear budgetary framework has been maintained and should be strengthened to become more binding. The dynamics of healthcare spending will also be better controlled with the strengthening of the early warning procedure on spending overruns, while fiscal governance has been improved with the decision of my authorities to ban the introduction of any new tax measure outside the budget law (Loi de Finances) or the social security budget law (Loi de Financement de la Sécurité Sociale). And finally, as mentioned by staff, the authorities are considering the introduction of a fiscal rule at the constitutional level. Specific proposals made by the working group chaired by Michel Camdessus will be discussed with major political parties in the coming weeks, with a view to introducing the rule in 2011.

\section{Pursuing structural reforms aimed at improving growth}

My authorities are determined to maintain the pace of structural reforms, in accordance with the commitments taken in the E.U and under the G20 MAP. This effort is being pursued in several directions to improve competitiveness, increase flexibility of the labor and product markets, and raise potential growth.

Raising competitiveness is clearly a key priority, and action has been taken in three main directions. First, the removal of the local business tax (Taxe Professionnelle) is a major improvement to the French tax system and will improve competitiveness and attractiveness to foreign investment. Second, as the rise in unit labor costs is one of the main causes of the deterioration in export performance over the recent period, the elimination of the discretionary increase in the minimum wage, as recommended by the IMF, should contribute to addressing this issue. Third, the launch of a $€ 35$ billion investment program (Grand Emprunt or Dépenses d'Avenir) designed to only have a marginal effect on public finances and to leverage private resources, is meant to boost capacities in education, research, and innovation, and promote a vibrant knowledge economy over the medium term. The success of the tax credit on research and development expenditures (credit d'impôt recherche ) will further contribute to stimulating potential growth.

Efforts are under way to improve the flexibility of the labor market and reduce structural unemployment. The impact of the crisis has been softened by the temporary unemployment schemes - as illustrated by the fact that France transitioned from above to below the Euro area average rate of unemployment during the crisis - and net job creations are expected to resume by end-year. My authorities are also pursuing their efforts to raise 
the employment rates, especially among vulnerable groups. The ongoing pension reform will complement the efforts made over the last few years (as mentioned above) to address the situation of senior workers and will have a fairly rapid impact since the increase in the legal retirement age will be phased in at a faster pace than under similar reforms in other countries. Fostering low-skilled workers' participation is also necessary and a consistent effort has been made over the last years to eliminate inactivity traps with the creation of the PIT tax credit (Prime pour l'emploi) and the recent introduction of the Working Solidarity Benefit (RSA).

Finally, my authorities are in full agreement with staff that further enhancing domestic competition would strengthen economic efficiency. They recognize that there is scope to build on recent measures such as those contained in the Economic Modernization Law and that the transposition of the E.U Services Directive is improving competition intensity in France. Ongoing reforms to boost competition in the utilities sectors will also be beneficial.

\section{Financial sector: maintaining stability}

The French financial sector has proved resilient to the crisis and remains solid. Banks have restored their profitability and strengthened their capital base, and are in a sound position to support the recovery. The results of the E.U stress testing exercise have confirmed this assessment: all the four French banks that have been tested (accounting for 80 percent of the total assets of the French banking system) have easily passed the most adverse scenario, with a Tier 1 ratio above 9 percent on average. This shows the resilience of the universal banking model that my authorities intend to preserve going forward.

My authorities are aware that the highly uncertain environment calls for maintained vigilance, but they consider that potential risks associated with banks' exposure to the so-called "EA5" (Box 7) should be nuanced. The geographical breakdown of exposures must be taken into account in that regard, as well as the nature of claims and the strength of French banks' capital base. French banks are indeed mainly exposed through loans to corporates rather than securities and government bonds, which suggests that potential losses, if any, would be gradual and slow. Strong revenue flows (the four biggest French banks posted a 28 percent increase in net income in the first quarter of 2010) would also help absorb such losses. Full transparency has been made on French banks' exposures to sovereign risk in Europe and it clearly shows that such exposures are manageable and that even the most adverse simulations would leave the banking system with a strong capital base.

My authorities are also actively engaged in the international financial regulatory reform. The introduction of a financial levy based on financial institutions' riskiest assets and the establishment of a framework for sound compensation practices in the financial industry demonstrate their commitment to avoiding excessive risk taking and promoting stability. This commitment also underpins the recent reform of the supervisory architecture, 
with the creation of a unique supervisor for banking and insurance and the establishment of a systemic risk board.

\section{International cooperation}

Finally, my authorities remain committed to international cooperation and provide significant financial support to the IMF to mitigate the impact of the crisis. The French commitment to the New Arrangements to Borrow (NAB) for SDR 18.6 billion has been ratified by the Parliament on June 7, 2010. In addition, France pledged a SDR 1.3 billion loan to the PRGT which will soon be effective. 